Review

\title{
Exercise as a pro-cognitive, pro-neurogenic and anti-inflammatory intervention in transgenic mouse models of Alzheimer's disease
}

\author{
Sinéad M. Ryan ${ }^{\mathrm{a}, \mathrm{b}, *}$, Áine M. Kelly ${ }^{\mathrm{a}, \mathrm{b}}$ \\ a Department of Physiology, Trinity Biosciences Institute, Trinity College Dublin, 152-160, Pearse Street, Dublin 2, Ireland \\ b Trinity College Institute of Neuroscience, Lloyd Building, Trinity College Dublin, Dublin 2, Ireland
}

\section{A R T I C L E I N F O}

\section{Article history:}

Received 16 December 2015

Received in revised form 22 March 2016

Accepted 30 March 2016

Available online 31 March 2016

\section{Keywords:}

Alzheimer's disease

Exercise

Cognition

Neurogenesis

Inflammation

\begin{abstract}
A B S T R A C T
It is now well established, at least in animal models, that exercise elicits potent pro-cognitive and proneurogenic effects. Alzheimer's disease (AD) is one of the leading causes of dementia and represents one of the greatest burdens on healthcare systems worldwide, with no effective treatment for the disease to date. Exercise presents a promising non-pharmacological option to potentially delay the onset of or slow down the progression of AD. Exercise interventions in mouse models of AD have been explored and have been found to reduce amyloid pathology and improve cognitive function. More recent studies have expanded the research question by investigating potential pro-neurogenic and anti-inflammatory effects of exercise. In this review we summarise studies that have examined exercise-mediated effects on $\mathrm{AD}$ pathology, cognitive function, hippocampal neurogenesis and neuroinflammation in transgenic mouse models of AD. Furthermore, we attempt to identify the optimum exercise conditions required to elicit the greatest benefits, taking into account age and pathology of the model, as well as type and duration of exercise.
\end{abstract}

(c) 2016 Elsevier B.V. All rights reserved.

\section{Contents}

1. Introduction .78

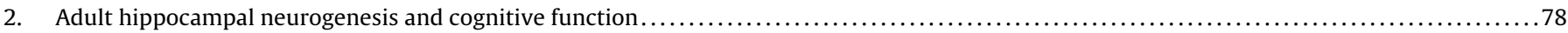

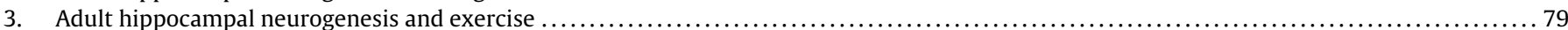

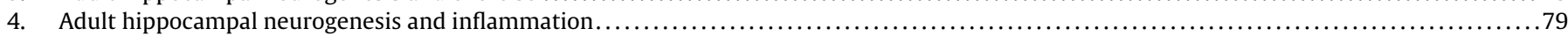

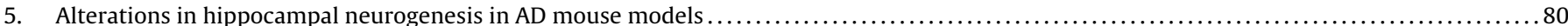

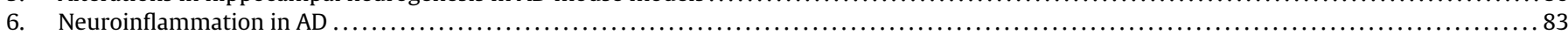

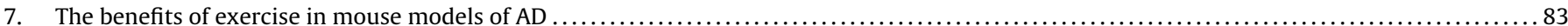

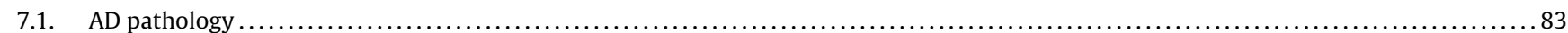

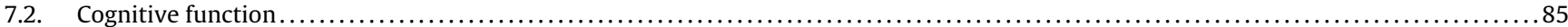

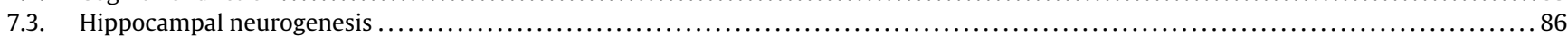

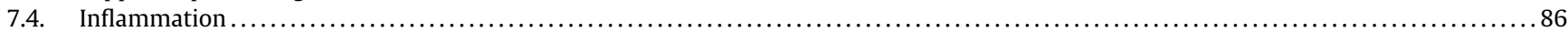

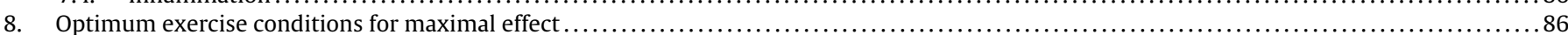

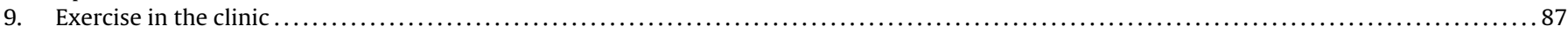

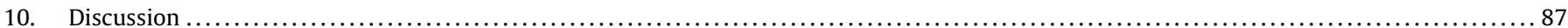

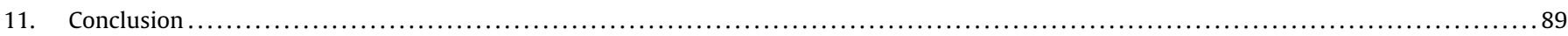

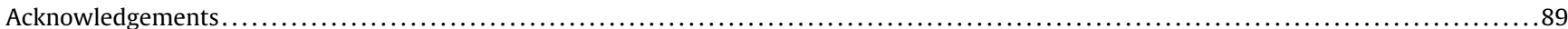

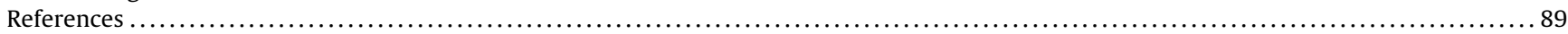

\footnotetext{
* Corresponding author at: Trinity College Institute of Neuroscience, Lloyd Building, Trinity College Dublin, Dublin 2, Ireland.

E-mail addresses: ryans43@tcd.ie (S.M. Ryan), aikelly@tcd.ie (Á.M. Kelly).
} 


\section{Introduction}

Dementia describes a group of age-associated conditions of which cognitive decline is a major feature. It is estimated that there are 46.8 million people living with dementia worldwide and with average life expectancy continuing to increase in the developed world, the number of sufferers is expected to reach 131.5 million in 2050 (http://www.worldalzreport2015.org/). Alzheimer's disease $(A D)$ is by far the greatest cause of dementia and is characterised by the onset of a gradual cognitive decline. Current treatments include cholinesterase inhibitors such as Donepezil, Rivastigmine and Galantamine; and Memantine which prevents glutamate-mediated neurotoxicity (Kalra and Khan, 2015). However, these drugs offer no long-term cure for the disease and often provide only short-term slow-down of disease progression.

The pathological features of AD are well-defined, however, a definitive diagnosis of the condition is still only possible at the postmortem stage. Accumulations of amyloid-ßeta $(A \beta)$ plaques and neurofibrillary tangles (NFTs) of hyperphosphorylated tau protein are the major pathological features of AD. Indeed assessment of $p$-tau ${ }^{+}$neurons in key brain structures allowed for the characterisation of disease progression by Braak and Braak (1991). NFTs are first observed in the transentorhinal region and subsequently spread into the limbic area. Finally, tangle pathology spreads to the neorcortical area causing mass destruction as is characteristic of end-stage AD (Braak and Braak, 1991). The hippocampus is one of the few regions in the brain in which neurogenesis occurs throughout life. There is now a significant body of research which indicates that neurogenesis is crucial to normal learning and memory processes, for a comprehensive review of this topic see Oomen et al. (2014). Current methodological limitations restrict the assessment of human neurogenesis to postmortem tissue thus, much of our knowledge to date has been learned from animal models. Changes in adult hippocampal neurogenesis have been reported in many of the available animal models of AD. Moreover, a number of studies of human AD brains have also reported alterations in hippocampal neurogenesis (Boekhoorn et al., 2006; Crews et al., 2010; Jin et al., 2004b). Given the evidence that supports a crucial role for hippocampal neurogenesis in learning and memory, understanding the mechanisms underlying changes in hippocampal neurogenesis in the AD brain could provide new avenues of investigation for drug development and therapeutics.

Hippocampal neurogenesis can be modulated both negatively and positively. Inflammation is regarded as a potent negative modulator of hippocampal neurogenesis and also induces cognitive deficits (Kohman and Rhodes, 2013). Chronic neuroinflammation is routinely reported in many neurodegenerative conditions, including $\mathrm{AD}$. Conversely, exercise is a robust positive modulator of hippocampal neurogenesis and also has cognitive enhancement effects in both animal models and human subjects (Yau et al., 2014). In animal models of $A D$, exercise has been shown to reduce $A D$ pathology by reducing $A \beta$ burden and tau hyperphosphorylation, and also to alleviate cognitive decline (Garcia-Mesa et al., 2012; Liu et al., 2013; Tapia-Rojas et al., 2016). However, to date, there has been little focus on exercise-induced effects on hippocampal neurogenesis and inflammation in $\mathrm{AD}$ models. The focus of this review is to summarise the current literature surrounding the use of exercise in animal models of $\mathrm{AD}$ and explore how the exercise interventions affect AD pathology, cognitive function, neurogenesis and inflammation. Furthermore, we will examine the exercise protocols employed across studies and attempt to define the optimum time-point for exercise intervention for maximal effects in animal models.

\section{Adult hippocampal neurogenesis and cognitive function}

Adult hippocampal neurogenesis describes the generation of new neurons and their subsequent maturation, survival and integration into existing circuitry. Neurogenesis occurs in the subgranular zone (SGZ) of the dentate gyrus (DG) region in the hippocampus. Adult hippocampal neurogenesis was first reported in the 1960's but available techniques at the time were unable to conclusively confirm that the new cells were in fact neurons (Altman, 1962). Identification of new neurons in the songbird (Paton and Nottebohm, 1984) allowed the hypothesis of adult neurogenesis to be revisited and the research field has grown significantly since then. Adult hippocampal neurogenesis has been reported in a range of species including rodents, guinea-pig, birds, sheep, nonhuman primates and humans (Brus et al., 2013). Recent evidence using carbon birthdating techniques suggest that approximately 700 new neurons are produced in the human hippocampus daily (Spalding et al., 2013). It is now widely regarded that the new neurons play a vital role in the processes of learning and new memory formation. Numerous studies have employed various methods of ablating neurogenesis in the hippocampus and have reported resultant deficits across a range of hippocampal-dependent cognitive tests including contextual fear conditioning (Farioli-Vecchioli et al., 2008; Saxe et al., 2006; Winocur et al., 2006), trace conditioning (Shors et al., 2001), Morris water maze (MWM) (Dupret et al., 2008; Snyder et al., 2005), object location task (Goodman et al., 2010) and delayed non-matching to sample task (Winocur et al., 2006). Of particular significance is that some studies controlled for hippocampal-independent tasks and found that ablation of neurogenesis did not impair performance in these tasks including cued fear conditioning (Farioli-Vecchioli et al., 2008; Saxe et al., 2006), delay conditioning (Shors et al., 2001) and the cued MWM (Snyder et al., 2005). Furthermore, Niibori et al.(2012) reported that ablation of hippocampal neurogenesis (by chemical and genetic methods) resulted in impaired spatial discrimination of similar, but not dissimilar, contexts. This study gives further support to the concept that pattern separation is not only a hippocampal-dependent task but is specifically neurogenesis-dependent.

We now know that a number of factors (both positive and negative) can influence the level of neurogenesis that occurs in the adult hippocampus. Kuhn et al. (1996) were the first to report a gradual age-related decline in hippocampal neurogenesis in the rat DG. This age-related decline in levels of neurogenesis is now well described in both mice and rats (Heine et al., 2004; Kang and Hebert, 2015; Rao et al., 2006). The age-related decline in neurogenesis is also accompanied by an age-related decline in cognitive function (Bolognin et al., 2014). Alterations in hippocampal neurogenesis have also been reported in a number of neurodegenerative diseases (AD and Huntington's disease) (Choi et al., 2014a; Moon et al., 2014; Perry et al., 2012), neurological diseases (epilepsy, ischaemia and traumatic brain injury) (D’Alessio et al., 2015; Matsuda et al., 2015; Villasana et al., 2014) and neuropsychiatric conditions (stress and depression) (Boldrini et al., 2012; Lucassen et al., 2015; Miller and Hen, 2015). Deficits in cognitive function have also been reported in some of these conditions. Another feature common to all these conditions is neuroinflammation; indeed neuroinflammation negatively regulates adult hippocampal neurogenesis (Ekdahl et al., 2003; Monje et al., 2003) as will be discussed in greater detail later in this review. Conversely, neurogenesis can be positively modulated by a number of factors. The act of learning new information, when the task is sufficiently difficult, has positive effects on levels of neurogenesis in the adult hippocampus (Curlik and Shors, 2011). Housing of laboratory rodents in enriched environments compared to standard laboratory housing increases hippocampal neurogenesis and also improves cognitive performance (Kempermann et al., 1997). It is worthwhile to note that when van Praag and colleagues 
studied the various components of the enriched environment, they determined the access to exercise in the enriched environment to be the key neurogenic stimulus (Kobilo et al., 2011). Finally, exercise has potent pro-neurogenic and pro-cognitive effects (van Praag et al., 1999a,b) as will be discussed below.

\section{Adult hippocampal neurogenesis and exercise}

Pro-neurogenic and pro-cognitive effects of exercise were first reported in 1999. Mice that were housed with a running wheel for 29 days had increased cell proliferation and cell survival in the DG, enhanced long term potentiation (LTP) and improvements in spatial memory when assessed in the MWM (van Praag et al., 1999a,b). Many research groups have independently reproduced these results and indeed have built upon this work further. Studies have demonstrated that voluntary wheel running (both in mice and rats) increases cell proliferation, neuronal differentiation and cell survival in the DG (Bruel-Jungerman et al., 2009; Garrett et al., 2012; Gibbons et al., 2014; Kobilo et al., 2011). Interestingly, it has been demonstrated that even a relatively short exercise exposure can be pro-neurogenic. Three days of wheel running increased numbers of $\mathrm{Ki}^{+} 7^{+}$proliferating cells in the rat DG (Patten et al., 2013), while in mice, three days of wheel running increased doublecortin (DCX) ${ }^{+}$newly-born neurons (Brandt et al., 2010) and cell proliferation and survival (Kronenberg et al., 2006). Forced treadmill exercise also has pro-neurogenic effects; exercise-induced increases in cell proliferation, neuronal differentiation and cell survival have all been reported in mice and rats trained on treadmill exercise protocols (Chang et al., 2008; Ferreira et al., 2011; Glasper et al., 2010). Regardless of exercise modality, additional structural measures have been reported to be modulated by exercise. A number of studies have described enhanced DG volume in exercising rodents (Clark et al., 2009, 2008). Enhanced dendritic structure, including dendrite length and branching, has also been observed in exercising vs sedentary animals (Glasper et al., 2010; Redila and Christie, 2006; Wu et al., 1985). The process of angiogenesis is believed to contribute to hippocampal neurogenesis to some degree; indeed the Gage laboratory observed dense clusters of proliferating cells in close association with the vasculature (Palmer et al., 2000). Treadmill exercise and voluntary wheel running have been reported to increase blood vessel density, numbers of glu-

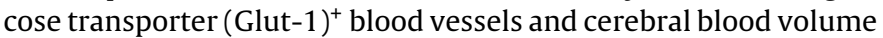
in animal models (Black et al., 1990; Pereira et al., 2007; Van der Borght et al., 2009). It is noteworthy that Pereira et al. (2007) correlated the exercise-induced increases in DG cerebral blood volume with postmortem measurements of cell survival. While there is still much focus on the signalling mechanisms by which exercise effects are mediated, upregulation of the neurotrophin brain-derived neurotrophic factor (BDNF) has been consistently reported following exercise interventions. Increased expression of hippocampal BDNF and its receptor TrkB has been observed following voluntary wheel running (Gibbons et al., 2014; Kobilo et al., 2011; Marlatt et al., 2012) and forced treadmill exercise (Chang et al., 2008; Griffin et al., 2009; Wu et al., 1985). At a behavioural level, improvements in spatial learning and memory, associative learning and recognition memory have all been observed in animals following exercise training. Mice housed with a running wheel perform better in the MWM compared to their sedentary counterparts (Clark et al., 2008; Gibbons et al., 2014; Mustroph et al., 2012), while exercising mice also outperformed their sedentary counterparts in the contextual fear conditioning task (Bhattacharya et al., 2015; Clark et al., 2008; Gibbons et al., 2014). Data from our laboratory has demonstrated that rats trained on a treadmill perform better than their sedentary counterparts in the novel object recognition and object displace- ment tasks of recognition and spatial memory respectively (Griffin et al., 2009).

\section{Adult hippocampal neurogenesis and inflammation}

Inflammation is a key pathological feature of many neurodegenerative, neurological and neuropsychiatric conditions. Moreover, the aging brain is characterised by an increasingly inflammatory environment. Recent microarray analysis of human brain tissue has demonstrated a significant age-related upregulation of genes associated with inflammation and immune system activation (Cribbs et al., 2012; Mohan et al., 2016; Nikas, 2013). In animal models of aging, studies have reported an exaggerated response (production of pro-inflammatory cytokines; microglial activation) following treatment with the bacterial endotoxin lipopolysaccharide (LPS) (Matt and Johnson, 2016; von Bernhardi et al., 2015). While LPS-induced neuroinflammation is a far from perfect model of the inflamed aging brain, it does demonstrate the differential response of young and aged neuroimmune cells to an inflammatory stimulus. Inflammation-mediated effects on hippocampal neurogenesis were first reported in 2003 in two key papers. In rats treated with LPS, Monje et al. (2003) reported an LPS-induced increase in numbers of activated microglia (ED $1^{+}$) accompanied by a decrease in numbers of newly-born neurons $\left(\mathrm{DCX}^{+}\right)$in the hippocampus. Administration of the non-steroidal anti-inflammatory drug (NSAID) indomethacin, blocked the LPS-induced effects. In a second study, LPS treatment again increased the number of activated microglia and also reduced the numbers of new neurons (BrdU/NeuN ${ }^{+}$) in the hippocampus (Ekdahl et al., 2003). Research into inflammation-mediated effects on hippocampal neurogenesis has grown substantially since these first reports. Many studies have characterised changes in neurogenesis in response to generalised inflammation (Ekdahl et al., 2003; Monje et al., 2003) and also to specific cytokines (Koo and Duman, 2008). Moreover, numerous studies have explored inflammation-mediated effects, not only on neurogenesis, but also on hippocampal-dependent memory function (Ben Menachem-Zidon et al., 2008). Other studies have focused solely on inflammation mediated effects on cognitive function independent of possible neurogenic effects (Adzovic et al., 2015; Dinel et al., 2014).

Recently, Boehme et al. (2014) reported an age-related increase in neuroinflammation as detected by increased expression of a panel of inflammatory cytokines and microglial markers in 24 month old aged mice compared to five month old adult counterparts. Along with this heightened inflammatory profile, the authors also observed a reduction in hippocampal neurogenesis. Whilst treatment with indomethacin attenuated the increase in inflammation, it failed to ameliorate the age-related reduction in hippocampal neurogenesis (Boehme et al., 2014). LPS-induced impairments to neuronal morphology have also been observed. A two week infusion of LPS increased numbers of activated microglial cells in the mouse DG; a reduction of total dendrite length of newborn neurons was also observed following LPS treatment (Llorens-Martin et al., 2014). Some studies have also examined how exposure to inflammation early in life affects neurogenesis and cognitive function later in life. Dinel et al. (2014) treated mice with a single dose of LPS on postnatal day (P) 14 and observed increased expression of pro-inflammatory cytokines in the hippocampus (tumour necrosis factor- $\alpha$ and interleukin-1 $\beta$ ) (TNF- $\alpha$ and IL-1 $\beta$ ) and plasma (interleukin-6) (IL-6, TNF- $\alpha$ and IL-1 $\beta$ ) $3 \mathrm{~h}$ later. Spatial memory was assessed in the MWM on P30 and P90 and no deficits were observed in LPS-treated mice. However, when mice were treated with a second dose of LPS on P90, they performed poorly in the MWM and had a reduced number of newly-born neurons in the hippocampus compared to saline-treated counterparts 
Sedentary AD mouse

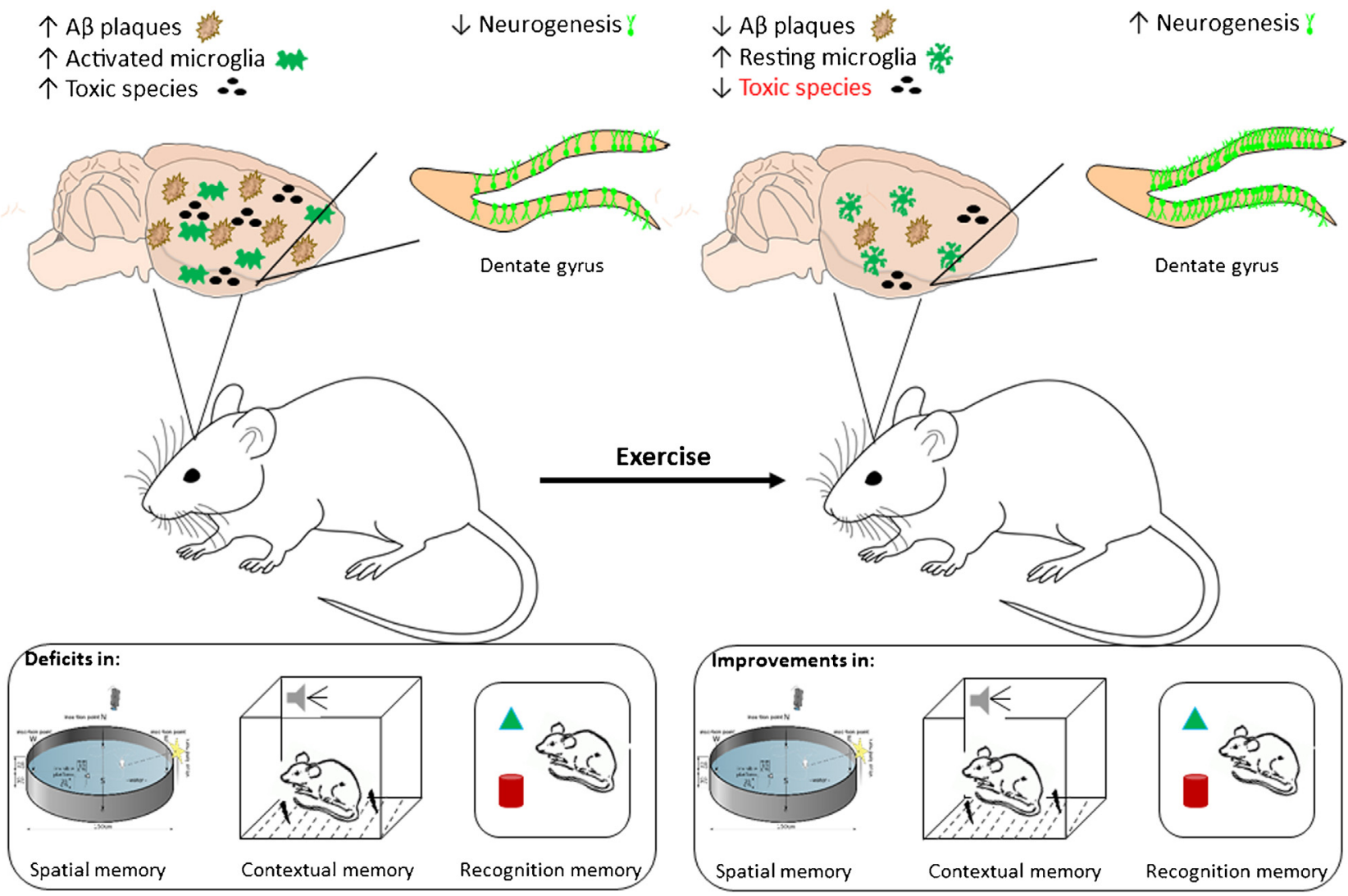

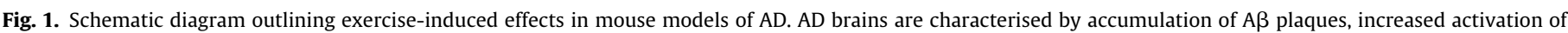

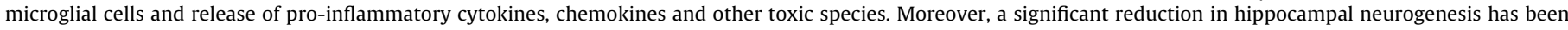

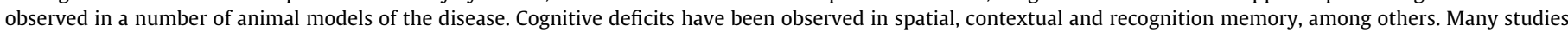

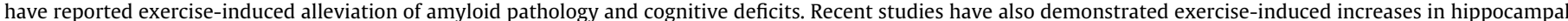
neurogenesis and decreases in microglial activation which suggests that other anti-inflammatory effects may occur in response to exercise.

(Dinel et al., 2014). Several other studies have reported similar trends in LPS-induced inflammation accompanied by deficits in cognitive function. A four week infusion of LPS intracerebroventricularly (i.c.v.) in adult and aged rats impaired performance of rats in the MWM at both ages tested and also increased microglial activation and mRNA and protein expression of the pro-inflammatory cytokines IL-1 $\beta$ and TNF- $\alpha$ (Adzovic et al., 2015). Aged male Wistar rats were impaired in the inhibitory avoidance task compared to their adult counterparts. The authors of the study identified a correlation between expression of pro-inflammatory cytokines and cognitive performance, with increased hippocampal IL-1 $\beta$ and TNF- $\alpha$ detected in aged rat samples (Lovatel et al., 2013). Specifically focusing on IL-1 $\beta$, impairments in long-term contextual and spatial memory were observed in a transgenic model of IL- $1 \beta$ overexpression. These impairments were accompanied by increased numbers of microglia and astrocytes, as well as increases in mRNA expression of several inflammatory markers (Hein et al., 2010). It is clearly evident from these studies and others that there is significant crosstalk between the immune and neural systems which permits inflammatory-mediated effects on neurogenesis and cognition. Studies that examine hippocampal neurogenesis, cognitive performance and inflammation simultaneously continue to yield interesting and novel insights into this emergent research area. Examining how these events are modulated by extrinsic factors, including exercise and $\mathrm{AD}$, could provide fresh insight into disease progression and potential therapeutic directions.

\section{Alterations in hippocampal neurogenesis in AD mouse models}

$\mathrm{AD}$ is foremost a progressive disorder of cognitive function. Recent advances in our understanding of the association between hippocampal neurogenesis and cognitive function provide a strong foundation for examining hippocampal neurogenesis in the $A D$ brain. Despite the strong evidence linking neurogenesis and cognitive function, there is as yet no accepted consensus on what neurogenic changes occur and the relevance of these changes to $\mathrm{AD}$ and its progression. To date there has been no compelling evidence published to ascertain the contribution of changes in hippocampal neurogenesis in the human AD brain. Technical limitations and small sample sizes make it difficult to draw any major conclusions from many of the studies thus far. Crews et al. (2010) reported a reduction in DCX immunoreactivity that correlated with increasing disease severity in a cohort of AD patients. Conversely, Jin et al. (2004b) found an increase in DCX expression as well as other neuronal markers; polysialylated neuronal cell adhesion molecule (PSA-NCAM), TUC-4 and NeuroD, in the AD brain. Results presented in this study however are only derived from western blotting analysis of tissue lysates rather than cell quantification. Perry et al. (2012) reported differential neurogenic effects in their AD patient cohort; Musashi- $1^{+}$and $\mathrm{ChAT}^{+}$cells decreased with increasing Braak progression, in contrast nestin ${ }^{+}$ and PSA-NCAM ${ }^{+}$cells increased with increasing Braak progression; no change was reported in numbers of $\beta$ III-tubulin ${ }^{+}$and $\mathrm{DCX}^{+}$ 
neurons in the SGZ (Perry et al., 2012). Finally, Boekhoorn et al. (2006) found that while there was an increase in $\mathrm{Ki}^{+} 7^{+}$proliferating cells in the hippocampus of pre-senile AD patients, this increase was largely attributed to glial and vasculature changes rather than neuronal changes. While small sample sizes continue to pose a problem when conducting postmortem studies of human patients, the current lack of a reliable and validated method of assessing neurogenesis in the human brain both pre- and postmortem presents perhaps the greatest impediment for researchers examining the role of $\mathrm{AD}$-associated changes in human hippocampal neurogenesis. Immunohistochemical markers, in particular DCX, are significantly affected by postmortem delay and their reliability as a means of assessing hippocampal neurogenesis in the human brain has been criticised (Boekhoorn et al., 2006). Moreover, data have been published which demonstrates that DCX can label mature astrocytes in the adult human neocortex (Verwer et al., 2007). Studies which have used DCX to assess neurogenesis in the human brain should thus be carefully and critically interpreted. For now at least, transgenic mouse models of $\mathrm{AD}$ represent the most appropriate method for examining how AD alters hippocampal neurogenesis.

Some conflicting data have also been reported across different animal models with both increases and decreases in hippocampal neurogenesis observed (Table 1). Cell proliferation (Li et al., 2015; Taniuchi et al., 2007), survival (Crews et al., 2010; Hamilton et al., 2010) and neuronal differentiation (Shruster and Offen, 2014; Valero et al., 2011) have all been observed to be reduced in mouse models of AD. Moreover, changes in neuronal morphology have also been reported in some studies (Biscaro et al., 2012; Valero et al., 2011). While many studies tend to examine hippocampal neurogenesis after the development of $A \beta$ plaques in these animal models, some changes in neurogenesis have been recorded before the appearance of $A \beta$ plaques. It has been reported that plaques develop from 9 to 12 months old in the Tg2576 model (Hsiao et al., 1996), however Krezymon et al. (2013) observed increased numbers of proliferating cells, reduced numbers of surviving cells and an overall reduction in dendritic complexity in three month old Tg2576 mice compared to their wild type (WT) counterparts. Furthermore, Demars et al. (2010) reported reduced numbers of proliferating cells and $\mathrm{DCX}^{+} / \mathrm{BrdU}^{+}$cells in two month old $\mathrm{APP}_{\mathrm{SWE}} / \mathrm{PS}-1 \Delta \mathrm{E} 9$ mice, despite $\mathrm{A} \beta$ plaques only developing in these mice from age three to six months old (Borchelt et al., 1997). Although the concept of a reduction in hippocampal neurogenesis preceding the development of $A \beta$ plaques may account for the onset of cognitive decline, further studies are required to pinpoint exactly where alterations in hippocampal neurogenesis occur in relation to other pathologies in the development of AD. There have also been reports of increased hippocampal neurogenesis in mouse models of AD (Ermini et al., 2008; Jin et al., 2004a; Mirochnic et al., 2009; Verdaguer et al., 2015; Yu et al., 2009). It is likely that differences in animal models, the age at which they are studied, extent of $A \beta$ pathology and method of assessment of neurogenesis, in particular BrdU administration protocols, all affect comparisons across these studies and may account for some of the differences observed with some studies reporting reductions in neurogenesis and others reporting increases. Of note in this regard are two studies from 2007 which investigated cell proliferation, by quantification of $\mathrm{BrdU}^{+}$cells in the DG of $\mathrm{APP}_{\mathrm{SWE}} / \mathrm{PS} 1 \triangle \mathrm{E} 9$ mice. Tchantchou et al. (2007) reported a robust reduction in cell proliferation in six month old $\mathrm{APP}_{\mathrm{SWE}} / \mathrm{PS}-1 \Delta \mathrm{E} 9$ mice vs WT counterparts following a seven day BrdU administration protocol in which mice received $\mathrm{BrdU}(75 \mathrm{mg} / \mathrm{kg})$ daily. No reference is made to whether male or female mice were used exclusively in this study. In contrast, Taniuchi et al. (2007) observed no difference (in either males or females) in cell proliferation in $\mathrm{APP}_{\mathrm{SWE}} / \mathrm{PS}-1 \Delta \mathrm{E} 9$ mice compared to their WT counterparts following a three day BrdU administration protocol in which mice received $\operatorname{BrdU}(50 \mathrm{mg} / \mathrm{kg})$ twice daily.
Do these two studies indicate that an AD-associated reduction in cell proliferation occurs rapidly within a relatively short timeframe of just one month? Or is it more likely that alterations in hippocampal cell proliferation and survival are being further clouded by different BrdU protocols in use across different mouse models, pathology, age and gender? Inclusion of data obtained from endogenous markers of cell proliferation, such as Ki67 and pHH3, in addition to BrdU cell quantification may aid in clarifying levels of cell proliferation at least. Current data from transgenic mouse models however, do suggest that alterations in hippocampal neurogenesis are an important pathological feature of progression of AD. Indeed, several studies have assessed cognitive function simultaneously with hippocampal neurogenesis. Deficits in spatial memory (Ben-Menachem-Zidon et al., 2014; Choi et al., 2014b; Iascone et al., 2013; Tapia-Rojas et al., 2016; Valero et al., 2011), spontaneous alternation (Li et al., 2015), contextual memory (Ben-MenachemZidon et al., 2014; Imbimbo et al., 2010) and recognition memory (Biscaro et al., 2012; Blanchard et al., 2010) have all been observed to occur alongside reductions in hippocampal neurogenesis. Interestingly, Yu et al. (2009) report that nine month old APP + PS-1 mice are impaired in the MWM task and have increased hippocampal neurogenesis. This finding further demonstrates the complexities in studying the role of hippocampal neurogenesis in AD and determining how it integrates with declining cognitive function as the disease progresses.

The literature surrounding the role of hippocampal neurogenesis in mouse models of AD has focused almost exclusively on mouse models with a strong amyloid pathology. Our knowledge of the contribution of hyperphosphorylated tau to alterations in hippocampal neurogenesis is not as well defined. Tau protein plays a key role in stabilising neuronal microtubules under physiological conditions. One of the tau isoforms, Tau-3R, is expressed by adult newborn neurons (Fuster-Matanzo et al., 2012). Interestingly, phosphorylated $\mathrm{tau}^{+}$cells are co-expressed with two markers of newborn neurons, DCX and NeuroD, in both a temporal and spatial fashion (Fuster-Matanzo et al., 2009; Hong et al., 2010). It is thus possible that more may be learned about the alterations in neurogenesis in AD by using tau-based mouse models over amyloid-based models given the need for tau expression under normal physiological conditions. As of yet however, there are insufficient studies examining hippocampal neurogenesis in tau mouse models. Recently, Komuro et al. (2015) reported a reduction in cell proliferation and neurogenesis in the DG of hTau mice from two months old and also reported $\mathrm{AT}^{+}\left(\mathrm{pTau}^{+}\right)$cells in the DG at this age, although tau aggregation has been previously seen in ten month old hTau mice (Komuro et al., 2015). In contrast, in the hTau-4R mice, hippocampal volume and cell number in the DG was increased compared to WT counterparts and increased cell survival and neurogenesis was observed in these mice when studied at two months old. Moreover, discrete structural deficits were observed in these mice as evident by reduced dendrite length, branching and filopodia spine density (Sennvik et al., 2007). Cognitive function and anxiety behaviours were assessed in an inducible mouse model facilitating overexpression of $\mathrm{N}$-tau in nestin ${ }^{+}$neural precursor cells (NPCs). Mice in which $\mathrm{N}$-tau was overexpressed exhibited a heightened anxiety profile and also performed worse in the MWM compared to control mice (Pristera et al., 2013). These behavioural changes were accompanied by significant reductions in cell proliferation, neurogenesis and cell survival, as well as an increase in cell death and microglial activation. Thus, studies to date in tau-based mouse models of $A D$ do not clarify the AD-associated alterations in hippocampal neurogenesis any further. It is however likely that the field would benefit greatly from more studies assessing neurogenesis in mouse models carrying tau mutations. 
Table 1

Changes in hippocampal neurogenesis in mouse models of AD.

\begin{tabular}{|c|c|c|}
\hline Reference & Age & Changes in neurogenesis \\
\hline \multicolumn{3}{|c|}{ Tg2576-A $\beta$ plaques develop from 9-12 months(Hsiao et al., 1996) } \\
\hline Li et al. (2015) & 12 months old & $\downarrow \mathrm{BrdU}^{+}$and $\mathrm{BrdU}^{+} / \mathrm{NeuN}^{+}$cells \\
\hline Choi et al. (2014b) & 13 months old & $\downarrow$ dendritic spine density \\
\hline Krezymon et al., (2013) & $3,5,12 \& 18$ months old & $\begin{array}{l}\downarrow \text { calbindin }{ }^{+} \text {cells in } 12 \text { \& } 18 \text { month old mice } \\
\uparrow \text { cell proliferation in } 3 \text { month old mice, age-related reduction in cell proliferation from } 5 \\
\text { months } \\
\downarrow \text { cell survival in } 3 \text { month old mice } \\
\downarrow \text { dendritic complexity in } 3 \text { month old mice }\end{array}$ \\
\hline Ben-Menachem-Zidon et al. (2014) & 12 months old & $\downarrow \mathrm{DCX}^{+}$cells \\
\hline Adlard et al. (2011) & $4 \& 14$ months old & $\downarrow$ apical spine density in $4 \& 14$ month old mice \\
\hline Imbimbo et al. (2010) & 15 months old & $\begin{array}{l}\downarrow \mathrm{DCX}^{+} \text {cells } \\
\downarrow \text { synaptophysin expression }\end{array}$ \\
\hline \multicolumn{3}{|c|}{ Triple transgenic mice-A $\beta$ plaques develop from 3-4 monthsOddo et al. (2003) } \\
\hline Shruster and Offen (2014) & 7 months old & $\begin{array}{l}\downarrow \mathrm{DCX}^{+} / \mathrm{EdU}^{+} \text {cells } \\
\downarrow \mathrm{EdU}^{+} / \mathrm{NeuN}^{+} \text {cells }\end{array}$ \\
\hline Hamilton et al. (2010) & $11 \& 18$ months old & $\begin{array}{l}\downarrow \text { cell proliferation }\left(\mathrm{Ki} 67^{+}\right) \text {in } 11 \text { month old mice } \\
\downarrow \mathrm{DCX} \mathrm{X}^{+} \text {cells in } 11 \text { and } 18 \text { month old mice } \\
\downarrow \text { cell survival }\left(\mathrm{BrdU}^{+}\right) \text {in } 11 \text { month old mice }\end{array}$ \\
\hline Blanchard et al. (2010) & 7-8 months old & $\begin{array}{l}\downarrow \text { cell survival }\left(\mathrm{BrdU}^{+}\right) \\
\downarrow \mathrm{BrdU}^{+} / \mathrm{NeuN}^{+} \text {cells } \\
\downarrow \mathrm{MAP} 2 \text { expression }^{\downarrow \text { synaptophysin expression }}\end{array}$ \\
\hline Rodriguez et al. (2008) & $2,3,4,6,9 \& 12$ months & $\downarrow \mathrm{pHH}^{+}$(proliferating cells) from 3 months old in female and from 9 months old in male mice \\
\hline
\end{tabular}

APP $_{\text {SWE }} /$ PS-1 $\triangle E$ E9-A $\beta$ plaques develop from 3-6 monthsBorchelt et al. (1997)

\begin{tabular}{|c|c|c|}
\hline Verdaguer et al. (2015) & $3 \& 12$ months old & $\begin{array}{l}\uparrow \text { Calbindin }^{+} \text {cells in } 3 \text { month old mice; } \downarrow \text { calbindin }^{+} \text {cells in } 12 \text { month old mice } \\
\downarrow \text { Calretinin }^{+} \text {cells in } 3 \text { month old mice; } \uparrow \text { calretinin }^{+} \text {cells in } 12 \text { month old mice }\end{array}$ \\
\hline Tapia-Rojas et al. (2016) & 8 months old & $\downarrow$ number of neurons in DG, CA1-CA2 and CA3 \\
\hline Demars et al. (2010) & 2 months old & $\begin{array}{l}\downarrow \text { cell proliferation }\left(\mathrm{BrdU}^{+}\right) \\
\downarrow \mathrm{DCX}^{+} / \mathrm{BrdU}^{+}\end{array}$ \\
\hline Ermini et al. (2008) & 8 months old & $\downarrow \mathrm{DCX}^{+}$cells \\
\hline Tchantchou et al. (2007) & $6 \& 22$ months old & $\downarrow$ cell proliferation $\left(\mathrm{BrdU}^{+}\right)$ \\
\hline Taniuchi et al. (2007) & $5 \& 9$ months old & $\begin{array}{l}\downarrow \text { cell proliferation (BrdU }+ \text { ) in } 9 \text { month mice, no change at } 5 \text { months old } \\
\downarrow \text { DCX+ cells in } 9 \text { month old mice, no change at } 5 \text { months old }\end{array}$ \\
\hline
\end{tabular}

APP23-A $\beta$ plaques develop from 6 monthsSturchler-Pierrat et al. (1997)

\begin{tabular}{|c|c|c|}
\hline Mirochnic et al. (2009) & $6 \& 18$ months old & $\begin{array}{l}\uparrow \text { cell survival }\left(\mathrm{BrdU}^{+}\right) \text {at } 6 \text { months old; no change at } 18 \text { months old } \\
\downarrow \text { calretinin }{ }^{+} \text {cells at } 6 \text { months and } 18 \text { months old } \\
\downarrow \mathrm{DCX}^{+} \text {cells at } 18 \text { months }\end{array}$ \\
\hline Ermini et al. (2008) & $5 \& 25$ months old & $\begin{array}{l}\uparrow \text { cell survival }\left(\mathrm{BrdU}^{+}\right) \text {and } \mathrm{BrdU}^{+} / \mathrm{NeuN}^{+} \text {cells in } 25 \text { month old mice } \\
\downarrow \mathrm{DCX}^{+} \text {cells in } 5 \text { month old; } \uparrow \mathrm{DCX}^{+} \text {cells in } 25 \text { month old mice }\end{array}$ \\
\hline
\end{tabular}

PDGF-APPSWE,IND $-A \beta$ plaques develop from 8-10 months old (Hsia et al., 1999)

\begin{tabular}{|c|c|c|}
\hline Jin et al. (2004a) & $3 \& 12$ months old & $\begin{array}{l}\uparrow \text { cell proliferation }\left(\mathrm{BrdU}^{+}\right) \text {in } 3 \& 12 \text { month old mice } \\
\uparrow \mathrm{DCX}^{+} \text {cells in } 3 \& 12 \text { month old mice }\end{array}$ \\
\hline Valero et al. (2011) & 6 months old & $\begin{array}{l}\downarrow \text { cell survival }\left(\mathrm{BrdU}^{+}\right) \text {and } \mathrm{BrdU}^{+} / \mathrm{NeuN}^{+} \text {cells } \\
\downarrow \mathrm{DCX}^{+} \text {cells and } \downarrow \mathrm{DCX} \text { cell morphology }\end{array}$ \\
\hline
\end{tabular}

APP(Tg2576)/PS-1(M146L)-A $\beta$ plaques develop from 3-6 months (Holcomb et al., 1998)

Biscaro et al. (2012) 4 months old $\quad \downarrow$ in $\mathrm{BrdU}^{+} / \mathrm{NeuN}^{+}$cells

Yu et al. (2009) $3 \& 9$ months old

$\downarrow$ in dendritic complexity

$\uparrow$ cell proliferation $\left(\mathrm{BrdU}^{+}\right)$in 9 month mice, no change at 3 months old

$\uparrow$ cell survival $\left(\mathrm{BrdU}^{+}\right)$and $\mathrm{BrdU}^{+} / \mathrm{NeuN}^{+}$cells in 9 month mice

$\uparrow \mathrm{DCX}^{+}$cells in 9 month old mice

5 x FAD-A $\beta$ plaques develop from 2 months (Oakley et al., 2006)

Moon et al. (2014) 2,3 \& 4 months old

$\downarrow \mathrm{DCX}^{+}$cells in 2, 3 \& 4 month old mice

$\downarrow$ HH3 and calretinin ${ }^{+}$cells in 2 month old mice

hAPPJ20-A $\beta$ plaques develop from 5-7 months (Mucke et al., 2000)

Iascone et al. (2013) 5-7 \& 13-15 months old

$\downarrow \mathrm{DCX}^{+}$cells at 5-7 and 13-15 months old

$\downarrow$ cell proliferation $\left(\mathrm{BrdU}^{+}\right)$at 5-7 and 13-15 months old

mThy1-hAPP $751-A \beta$ plaques develop from 3-4 monthsRockenstein et al. (2001)

$\begin{array}{lll}\text { Crews et al. (2010) } & 7 \text { months old } & \downarrow \text { cell survival }\left(\mathrm{BrdU}^{+}\right) \\ & & \downarrow \mathrm{DCX}^{+} \text {cells }\end{array}$

$\downarrow \mathrm{DCX}^{+}$cells

$\downarrow \mathrm{SOX}^{+}$cells

PD-APP-A $\beta$ plaques develop from 6-9 months (Games et al., 1995)

Donovan et al. (2006) $2 \& 12$ months old

$\downarrow$ cell proliferation and survival $\left(\mathrm{BrdU}^{+}\right)$in 12 month mice, no change at 2 months old

$\downarrow \mathrm{DCX}_{+}$cells in 12 month old mice

No change in $\mathrm{DCX}^{+} / \mathrm{BrdU}^{+}$cells and $\mathrm{BrdU}^{+} / \mathrm{NeuN}^{+}$cells 


\section{Neuroinflammation in AD}

Similar to several other neurodegenerative conditions, neuroinflammation is considered a major pathological feature of AD. Indeed, there is an ever-expanding pool of data from both human studies and animal models of AD that highlights the crucial role played by neuroinflammation in $\mathrm{AD}$. For recent reviews of the literature in this field, the reader is directed to the following comprehensive articles (Heneka et al., 2015; Heppner et al., 2015; McGeer and McGeer, 2013; Shadfar et al., 2015). Epidemiological and clinical studies in human AD patients have provided some interesting perspectives on neuroinflammation and in some cases have stimulated further work in animal models of the disease. Glial cell dysfunction is evidenced by the observation of reactive astrocytes and microglia in the postmortem AD brain (Mandrekar-Colucci and Landreth, 2010; Nagele et al., 2003). Increased expression of pro-inflammatory cytokines have been reported (Sastre et al., 2006) and have been associated with increasing the risk of conversion from the mild cognitive impairment to dementia phase of AD (Tarkowski et al., 2003). Moreover, genetic studies have identified polymorphisms of several immune-related molecules that suggest risk for AD development (Sastre et al., 2006). Finally, epidemiological evidence suggests that NSAID treatment lowers the risk for onset of the disorder, however, to date clinical trials of NSAIDs in AD patients have not yielded any success (McGeer and McGeer, 2013).

Focusing specifically on animal models of AD, there are a multitude of studies which have explored neuroinflammation and anti-inflammatory strategies in these models. In the APP $\mathrm{SWE}_{\mathrm{PS}} / \mathrm{P}$ $1 \triangle \mathrm{E} 9$ model, increased mRNA expression of the microglial markers Iba1 and CD68 have been reported in mice as early as three months old (Johansson et al., 2015). Indeed, continued upregulation of these markers have been reported in aged mice of 14 and 24 months old (Minogue et al., 2014). Furthermore, increased expression of proinflammatory cytokines has also been characterised in this model with increased mRNA expression of IL- $1 \beta$ and TNF- $\alpha$ apparent from eight months old (Hickman et al., 2008) and persisting up to 24 months old (Minogue et al., 2014). Similar evidence of neuroinflammation has been reported in the triple transgenic AD model with increased numbers of resting and activated microglia observed at nine and twelve months old respectively (Rodriguez et al., 2010) and increased mRNA expression of a panel of pro-inflammatory cytokines in 16 month old transgenic mice (Zaheer et al., 2013). There have also been data published surrounding the impact of an inflammatory environment on progression of disease pathology. Ghosh et al. (2013) crossed the triple transgenic mouse with the IL$1 \beta$ XAT mouse to induce sustained IL- $1 \beta$ expression in their model. One month of IL-1 $\beta$ expression enhanced microglial and astrocytic activation and increased tau hyperphosphorylation (Ghosh et al., 2013). Krstic et al. (2012) presented compelling data for the role of an immune challenge in driving AD-like neuropathology. In the study, WT mice were challenged during late gestation with the viral mimic Polyinosinic-polycytidylic acid (Poly I:C) and postmortem tissue analyses were carried out from three weeks to twenty months old. The authors reported that the pre-natal immune challenge produced a chronic elevation of inflammatory cytokines, increased levels of hippocampal amyloid precursor protein (APP) and tau phosphorylation and deficits in working memory in aged mice. Moreover, when a second immune challenge was administered during adulthood, the effects were exacerbated and found to mimic AD-like pathology (Krstic et al., 2012). This study provides evidence that an immune challenge alone can potentially prime the brain for development of neurodegenerative pathology later in life. Antiinflammatory strategies have also been explored in other animal models. For example, Tg2576 mice injected intrahippocampally with an adeno-associated virus expressing the anti-inflammatory cytokine interleukin-4 (IL-4) displayed a reduction in astrocytosis and microgliosis as well as decreased amyloid plaque number and load. These changes were accompanied by improvements in working memory and hippocampal neurogenesis (Kiyota et al., 2010). Conversely, in APP/PS-1 KI mice treated with an experimental therapeutic that attenuates cytokine production, the neuroinflammatory phenotype was ameliorated, however, there was no effect observed on amyloid pathology (Bachstetter et al., 2012).

Data from human studies and animal models have contributed substantially to our understanding of neuroinflammatory processes in AD. Moreover, they have highlighted the importance of giving consideration to some form of anti-inflammatory intervention in the treatment of AD. The strong links between cognition, hippocampal neurogenesis and inflammation have been alluded to in the previous sections and with exercise known to be procognitive and pro-neurogenic, the potential for exercise-induced alterations to neuroinflammation in animal models, and indeed human patients, of AD has only slightly been explored to date but is indeed worthy of further research.

\section{The benefits of exercise in mouse models of AD}

It is clear from the studies discussed to date in this article that there is much crosstalk between hippocampal neurogenesis, inflammation and cognitive function, generally and with specific reference to $\mathrm{AD}$. Interestingly, the first studies which examined environmental influences on $\mathrm{AD}$ used the environmental enrichment model. $\mathrm{APP}_{\mathrm{SWE}} / \mathrm{PS}-1 \Delta \mathrm{E} 9$ mice which were housed under environmental enrichment conditions from two months of age to 8.5 months old surprisingly displayed an exacerbated amyloid pathology compared to their counterparts housed under standard conditions (Jankowsky et al., 2003). This finding could be explained however by the low ratio of running wheels to mice in the cage, which is in line with more recent work from the van Praag laboratory highlighting the importance of the running wheel in the enriched environment (Kobilo et al., 2011). Subsequent studies reported an amelioration in amyloid pathology in $\mathrm{APP}_{\mathrm{SWE}} / \mathrm{PS}-1 \Delta \mathrm{E} 9$ mice and improvements in cognitive function in the APPSWE mice housed in an enriched environment (Arendash et al., 2004; Lazarov et al., 2005) Building upon these data, studies have also investigated the use of exercise exclusively in mouse models of $\mathrm{AD}$ and have made some interesting observations. Table 2 summarises the exercise-induced effects on AD pathology, cognitive function, hippocampal neurogenesis and inflammation across a number of transgenic mouse models of $\mathrm{AD}$.

\subsection{AD pathology}

Voluntary wheel running and treadmill running protocols, have both been consistently found to reduce AD pathology in the brains of transgenic mice (Table 2). Voluntary wheel running and treadmill running both reduce $A \beta$ plaque number, soluble $A \beta$ protein and tau phosphorylation (Belarbi et al., 2011; Cho et al., 2015; Tapia-Rojas et al., 2016; Um et al., 2011; Yuede et al., 2009; Zhao et al., 2015). Most recently, evidence was published demonstrating a doseresponse effect for treadmill exercise-mediated reduction of soluble $A \beta 40$ and $A \beta 42$ protein, with high intensity runners having the greatest reduction in $A \beta 40 / 42$ levels (Moore et al., 2015). A number of studies, however, report no exercise-induced alleviation of $\mathrm{AD}$ pathology. Xu et al. (2013) found that six weeks of wheel running ( 2 h per day) had no effect on $\beta$ and $\gamma$ secretase expression and $A \beta 42$ protein in ten month old $\mathrm{APP}_{\mathrm{SWE}} / \mathrm{PS}-1 \Delta \mathrm{E} 9$ mice. However, given that Zhao et al. (2015) report that five months of treadmill running by 12 month old mice, of the same strain, reduces soluble $A \beta 42$ protein, we may speculate that the exercise regime adopted by Xu et al. (2013) was insufficient rather than the pathology being too far 
Table 2

Exercise-induced effects in mouse models of AD.

\begin{tabular}{|c|c|c|c|c|c|c|}
\hline Reference & Age & Exercise regime & AD pathology & Cognitive function & $\begin{array}{l}\text { Hippocampal } \\
\text { neurogenesis }\end{array}$ & Inflammation \\
\hline \multicolumn{7}{|c|}{$\mathrm{APP}_{\mathrm{SWE}} / \mathrm{PS}-1 \Delta \mathrm{E}-\mathrm{A} \beta$ plaques develop from 3 to 6 months (Borchelt et al., 1997) } \\
\hline Zhao et al. (2015) & $3 \& 12$ months old & $\begin{array}{l}\text { Five month } \\
\text { treadmill running } \\
\text { protocol }\end{array}$ & $\begin{array}{l}\downarrow \mathrm{A} \beta \text { plaque } \\
\text { number in young } \\
\text { but not aged } \\
\text { runners } \\
\downarrow \text { Soluble } A \beta 42 \\
\text { protein in young } \\
\text { and aged runners }\end{array}$ & $\begin{array}{l}\text { Improved } \\
\text { performance in } \\
\text { MWM in young } \\
\text { and aged runners }\end{array}$ & $\begin{array}{l}\uparrow \text { Synaptic } \\
\text { plasticity in aged } \\
\text { runners }\end{array}$ & \\
\hline Lin et al. (2015) & 6 weeks old & $\begin{array}{l}3.5 \text { month } \\
\text { treadmill running } \\
\text { protocol }\end{array}$ & $\begin{array}{l}\downarrow \text { Hippocampal } \\
\text { soluble } A \beta 40 \& \\
A \beta 42 \text { protein }\end{array}$ & $\begin{array}{l}\text { Enhanced short } \\
\text { term and long term } \\
\text { contextual memory }\end{array}$ & $\begin{array}{l}\uparrow \text { Dendritic } \\
\text { arborisation in CA1 } \\
\& \text { CA3 }\end{array}$ & \\
\hline $\begin{array}{l}\text { Tapia-Rojas et al. } \\
\quad(2016)\end{array}$ & 5 months old & $\begin{array}{l}\text { Ten weeks of } \\
\text { voluntary wheel } \\
\text { running }\end{array}$ & $\begin{array}{l}\downarrow \mathrm{A} \beta \text { oligomers and } \\
\text { plaque deposits } \\
\downarrow p \text {-Tau }{ }^{+} \text {cells }\end{array}$ & $\begin{array}{l}\text { Improved } \\
\text { performance in } \\
\text { MWM }\end{array}$ & $\begin{array}{l}\uparrow \text { Neuronal number } \\
\text { in CA3 and DG } \\
\uparrow \text { Cell proliferation } \\
\left(\mathrm{BrdU}^{+}\right) \text {and } \\
\mathrm{DCX}^{+} / \mathrm{BrdU}^{+} \text {cells in } \\
\mathrm{SGZ}\end{array}$ & $\downarrow \mathrm{GFAP}^{+}$cells \\
\hline Bo et al. (2014) & 3 months old & $\begin{array}{l}20 \text { weeks treadmill } \\
\text { running protocol }\end{array}$ & $\downarrow \mathrm{A} \beta$ protein & $\begin{array}{l}\text { Improvements in } \\
\text { spontaneous } \\
\text { alternation and } \\
\text { passive avoidance }\end{array}$ & & \\
\hline Xu et al. (2013) & 10 month old & $\begin{array}{l}\text { Six weeks wheel } \\
\text { running, two hours } \\
\text { per day }\end{array}$ & $\begin{array}{l}\text { No effect on } \beta \& \gamma \\
\text { secretase } \\
\text { expression and } \\
A \beta 42 \text { protein levels }\end{array}$ & $\leftrightarrow \mathrm{MWM}$ & & $\begin{array}{l}\text { No reduction in } \\
\text { GFAP }^{+} \text {and Iba- } 1^{+} \\
\text {cells }\end{array}$ \\
\hline Liu et al. (2013) & 3 months old & $\begin{array}{l}\text { Five month } \\
\text { treadmill running } \\
\text { protocol }\end{array}$ & $\begin{array}{l}\downarrow \mathrm{A} \beta \text { plaque } \\
\text { number and } \\
\text { burden } \\
\downarrow \mathrm{A} \beta 42 \text { protein } \\
\downarrow \text { Tau } \\
\text { phosphorylation }\end{array}$ & & & \\
\hline Liu et al. (2011) & 3 months old & $\begin{array}{l}\text { Five month } \\
\text { treadmill running } \\
\text { protocol }\end{array}$ & & $\begin{array}{l}\text { Improved } \\
\text { performance in } \\
\text { MWM }\end{array}$ & & \\
\hline Ke et al. (2011) & 7-8 \& 24 month old & $\begin{array}{l}\text { Five week } \\
\text { treadmill running } \\
\text { protocol }\end{array}$ & $\begin{array}{l}\downarrow \mathrm{A} \beta 42 \text { expression } \\
\text { in adult mice } \\
\leftrightarrow \mathrm{A} \beta \text { plaque } \\
\text { number in aged } \\
\text { mice }\end{array}$ & $\begin{array}{l}\leftrightarrow \text { passive } \\
\text { avoidance } \\
\text { Improved } \\
\text { performance in } \\
\text { MWM in aged, not } \\
\text { adult mice }\end{array}$ & & $\begin{array}{l}\downarrow \text { Microglial } \\
\text { activation in adult } \\
\text { and aged mice }\end{array}$ \\
\hline \multicolumn{7}{|c|}{ Tg2576-A $\beta$ plaques develop from 9 to 12 months (Hsiao et al., 1996) } \\
\hline Moore et al. (2015) & 3 months old & $\begin{array}{l}\text { Three month } \\
\text { treadmill running } \\
\text { protocol }\end{array}$ & $\begin{array}{l}\downarrow \text { Hippocampal and } \\
\text { cortical soluble } \\
A \beta 40 \text { and } A \beta 42 \\
\text { protein }\end{array}$ & & & \\
\hline Yuede et al. (2009) & 5 months old & $\begin{array}{l}16 \text { weeksof } \\
\text { voluntary wheel } \\
\text { running or } \\
\text { treadmill running }\end{array}$ & $\downarrow \mathrm{A} \beta$ plaques & $\begin{array}{l}\uparrow \text { Recognition } \\
\text { memory by wheel } \\
\text { running, not } \\
\text { treadmill }\end{array}$ & $\begin{array}{l}\uparrow \text { Hippocampal } \\
\text { volume }\end{array}$ & \\
\hline $\begin{array}{l}\text { Parachikova et al. } \\
\text { (2008) }\end{array}$ & 15-19 months old & $\begin{array}{l}\text { Three weeks of } \\
\text { voluntary wheel } \\
\text { running }\end{array}$ & $\begin{array}{l}\text { No effect on } \\
\text { amyloid pathology }\end{array}$ & $\begin{array}{l}\text { Improved } \\
\text { performance in } \\
\text { radial arm water } \\
\text { maze }\end{array}$ & & $\begin{array}{l}\uparrow i l-11, \text { cxcl1 \& } \\
\text { cxcl12 mRNA }\end{array}$ \\
\hline Nichol et al. (2007) & 16-18 months old & $\begin{array}{l}\text { Three weeks of } \\
\text { voluntary wheel } \\
\text { running }\end{array}$ & & $\begin{array}{l}\text { Improved } \\
\text { performance in the } \\
\text { radial arm water } \\
\text { maze }\end{array}$ & & \\
\hline \multicolumn{7}{|c|}{ Tg-NSE/hPS-2-A $\beta$ plaques develop from 12 months old (Hwang et al., 2002) } \\
\hline Koo et al. (2013) & 24 months old & $\begin{array}{l}\text { Three month } \\
\text { treadmill running } \\
\text { protocol }\end{array}$ & & $\begin{array}{l}\text { Improved } \\
\text { performance in } \\
\text { MWM }\end{array}$ & & $\begin{array}{l}\downarrow \text { COX2 protein } \\
\downarrow \text { Caspase-3 } \\
\text { protein }\end{array}$ \\
\hline Um et al. (2011) & 24 months old & $\begin{array}{l}\text { Three month } \\
\text { treadmill running } \\
\text { protocol }\end{array}$ & $\begin{array}{l}\downarrow \text { Hippocampal } \\
\text { A } \beta 42 \text { protein } \\
\downarrow \text { Tau } \\
\text { phosphorylation }\end{array}$ & $\begin{array}{l}\text { Improved } \\
\text { performance in } \\
\text { MWM }\end{array}$ & & $\begin{array}{l}\downarrow \text { COX2 protein } \\
\downarrow \text { Caspase-3 } \\
\text { protein }\end{array}$ \\
\hline Cho et al. (2003) & 12 months old & $\begin{array}{l}\text { Three month } \\
\text { treadmill running } \\
\text { protocol }\end{array}$ & $\downarrow A \beta 42$ protein & $\begin{array}{l}\text { Improved } \\
\text { performance in } \\
\text { MWM }\end{array}$ & & \\
\hline
\end{tabular}


Table 2 (Continued)

\begin{tabular}{|c|c|c|c|c|c|c|}
\hline Reference & Age & Exercise regime & AD pathology & Cognitive function & $\begin{array}{l}\text { Hippocampal } \\
\text { neurogenesis }\end{array}$ & Inflammation \\
\hline \multicolumn{7}{|c|}{ Triple transgenic mice-A $\beta$ plaques develop from 3 to 4 months (Oddo et al., 2003) } \\
\hline Cho et al. (2015) & $4 \& 24$ months old & $\begin{array}{l}\text { Twelve weeks } \\
\text { treadmill running } \\
\text { protocol }\end{array}$ & $\begin{array}{l}\text { Adult mice: } \downarrow \\
p \text {-Tau205 } \\
\text { expression in } \\
\text { cortex and } \\
\text { hippocampus } \\
\text { Aged mice: } \downarrow \text { A } \beta 42 \\
\text { expression and } \\
\text { plaque number } \\
\downarrow p \text {-Tau expression } \\
\downarrow \text { BACE- } 1 \text { \& CTF } \beta \\
\text { expression }\end{array}$ & $\begin{array}{l}\text { Improved } \\
\text { performance in } \\
\text { MWM of both adult } \\
\text { and aged mice }\end{array}$ & & \\
\hline Revilla et al. (2014) & 1 month old & $\begin{array}{l}\text { Six months of } \\
\text { voluntary wheel } \\
\text { running }\end{array}$ & $\begin{array}{l}\leftrightarrow \mathrm{A} \beta 42 \text { or } p \text {-Tau } \\
\text { expression }\end{array}$ & & & \\
\hline Marlatt et al. (2013) & 9 months old & $\begin{array}{l}\text { One or ten months } \\
\text { of voluntary wheel } \\
\text { running }\end{array}$ & & $\begin{array}{l}\text { Mice exhibited no } \\
\text { deficits in carrying } \\
\text { out MWM task }\end{array}$ & $\uparrow$ Cell survival & \\
\hline $\begin{array}{l}\text { Garcia-Mesa et al. } \\
\quad(2012)\end{array}$ & 6 months old & $\begin{array}{l}\text { Six months of } \\
\text { voluntary wheel } \\
\text { running }\end{array}$ & $\begin{array}{l}\downarrow \mathrm{A} \beta 42 \text { expression } \\
\leftrightarrow p \text {-Tau } \\
\text { expression }\end{array}$ & $\begin{array}{l}\text { Improved } \\
\text { performance in } \\
\text { MWM }\end{array}$ & & \\
\hline Rodriguez et al. (2011) & 3 months old & $\begin{array}{l}\text { Six months of } \\
\text { voluntary wheel } \\
\text { running }\end{array}$ & & & $\begin{array}{l}\uparrow \text { Cell proliferation } \\
\left(\mathrm{HH}^{+} \text {cells }\right)\end{array}$ & \\
\hline \multicolumn{7}{|c|}{ TgCRND8-A $\beta$ plaques develop from three months old (Chishti et al., 2001) } \\
\hline Walker et al. (2015) & 2 months old & $\begin{array}{l}\text { Four months of } \\
\text { voluntary wheel } \\
\text { running }\end{array}$ & $\downarrow \mathrm{A} \beta 42$ protein & & & \\
\hline Adlard et al. (2005) & 1 month old & $\begin{array}{l}\text { Five months of } \\
\text { voluntary wheel } \\
\text { running }\end{array}$ & $\downarrow A \beta$ expression & $\begin{array}{l}\text { Improved } \\
\text { performance in } \\
\text { MWM }\end{array}$ & & \\
\hline \multicolumn{7}{|c|}{ THY-Tau22-p-Tau ${ }^{+}$cells develop from three months old (Schindowski et al., 2006) } \\
\hline Belarbi et al. (2011) & 3 months old & $\begin{array}{l}\text { Nine months of } \\
\text { voluntary wheel } \\
\text { running }\end{array}$ & $\begin{array}{l}\downarrow \text { Abnormal } p \text {-Tau } \\
\text { expression }\end{array}$ & $\begin{array}{l}\text { Improvements in } \\
\text { spontaneous } \\
\text { alternation }\end{array}$ & & $\begin{array}{l}\text { No effect on GFAP } \\
\text { cells and } i l-1 \beta \text {, } \\
\text { tnf- } \alpha \text { and } c d 68 \\
\text { mRNA in the } \\
\text { hippocampus }\end{array}$ \\
\hline \multicolumn{7}{|c|}{ APP23-A $\beta$ plaques develop from 6 months (Sturchler-Pierrat et al., 1997) } \\
\hline Mirochnic et al. (2009) & $6 \& 18$ months old & $\begin{array}{l}\text { Ten days of } \\
\text { voluntary wheel } \\
\text { running }\end{array}$ & $\begin{array}{l}\text { In } 18 \text { month old } \\
\text { mice, no effect on } \\
\text { plaque load but } \downarrow \\
a \beta \text { and app } \\
\text { hippocampal } \\
\text { mRNA }\end{array}$ & & $\begin{array}{l}\downarrow \text { Cell survival in } 6 \\
\text { month old and no } \\
\text { effect at } 18 \text { months } \\
\uparrow \mathrm{BrdU}^{+} / \mathrm{NeuN}^{+} \\
\text {cells in } 6 \text { month old }\end{array}$ & \\
\hline
\end{tabular}

progressed for exercise to mediate an effect. Similarly, Parachikova et al. (2008) found no effect on amyloid pathology in 15-19 month old Tg2576 mice housed with a running wheel for three weeks. Furthermore, housing of one month old triple transgenic mice with a running wheel for six months had no effect on $A \beta 42$ or $p$-Tau expression (Revilla et al., 2014). This however contrasts with the data presented in a recent study from Cho et al. (2015). In this study, it was reported that $A \beta$ plaque number and soluble $A \beta 42$ expression is reduced in 27 month old mice but not seven month old mice following 12 weeks of treadmill running. Similarly, GarciaMesa et al. (2012) reported reduced $A \beta 42$ expression in 12 month old triple transgenic mice who had been housed with a running wheel for six months. The mechanism by which exercise reduces amyloid pathology has not been explored in significant detail with many studies simply demonstrating exercise-induced reductions in amyloid plaque number/density and levels of $A \beta 42$. However, recent data suggests that exercise can modulate the degradation and clearance of $A \beta$. Moore et al. (2015) reported that three months of treadmill training, by three month old $\mathrm{Tg} 2576$ mice, upregulated proteins associated with proteolytic degradation of $A \beta$ (neprilysin, matrix metallopeptidase 9 and insulin degrading enzyme), $A \beta$ efflux across the blood-brain barrier (Low density lipoprotein receptor-related protein-1 (LRP-1)), and cellular uptake (heat shock protein 70) in a dose-dependent manner. Lin et al. (2015) also observed an upregulation of LRP-1 in the amygdala and hippocampus of $\mathrm{APP}_{\mathrm{SWE}} / \mathrm{PS}-1 \Delta \mathrm{E} 9$ mice trained on a treadmill for three and a half months. While other mechanisms may yet be elucidated, exercise-mediated effects on mechanisms of amyloid degradation and clearance provide a plausible means by which this peripheral factor can alter $\mathrm{AD}$ neuropathology in transgenic models.

\subsection{Cognitive function}

Exercise has been largely observed to be a pro-cognitive modulator in transgenic mouse models of AD (Table 2). Spatial learning and memory (Adlard et al., 2005; Liu et al., 2011), contextual memory (Lin et al., 2015) and recognition memory (Yuede et al., 2009) are all improved following exercise training. However, Xu et al. (2013), having failed to observe an exercise-induced amelioration of AD pathology, also found that six weeks of wheel running did not improve the performance of $\mathrm{APP}_{\mathrm{SWE}} / \mathrm{PS}-1 \Delta \mathrm{E} 9$ mice in the MWM. Also in the APP $\mathrm{SWE}_{\mathrm{SW}} / \mathrm{PS}-1 \Delta \mathrm{E} 9$ model, Ke et al. (2011) reported that five weeks of treadmill running did not improve spatial learning or passive avoidance behaviours in seven to eight month old mice, but spatial learning was improved in their 24 month old counterparts trained on the same protocol. Whether these shorter bouts of exer- 
cise are in fact sufficient to consistently confer significant benefits on cognitive function remains to be seen.

\subsection{Hippocampal neurogenesis}

Few studies have in fact characterised the neurogenic response in $\mathrm{AD}$ mice exposed to exercise. However, to date all studies that have examined neurogenesis report pro-neurogenic effects. Synaptic plasticity (Zhao et al., 2015), dendritic arborisation (Lin et al., 2015), cell proliferation and neuronal differentiation (Tapia-Rojas et al., 2016) are all increased in $\mathrm{APP}_{\mathrm{SWE}} / \mathrm{PS}-1 \Delta \mathrm{E} 9$ mice that have undergone exercise training. Yuede et al. (2009) report increased hippocampal volume in five month old Tg2576 mice housed with a running wheel or exercised on a treadmill for 16 weeks. Cell proliferation (Rodriguez et al., 2011) and cell survival (Marlatt et al., 2013) was increased in triple transgenic mice housed with a running wheel. Finally, in the APP23 mouse model of amyloidosis, ten days of voluntary wheel running reduced cell survival in six month old mice but increased neuronal differentiation (Mirochnic et al., 2009). Furthermore, several studies have reported increased expression of synaptic plasticity-related proteins, key growth factors and transcription factors that are associated with exercise-mediated effects on hippocampal neurogenesis such as synaptophysin and postsynaptic density protein 95 (PSD-95) (Cho et al., 2015; Revilla et al., 2014), BDNF (Cho et al., 2015; Um et al., 2011), nerve growth factor (NGF) (Um et al., 2011), glialderived neurotrophic factor (GDNF) (Revilla et al., 2014), cAMP response element-binding protein (CREB) (Um et al., 2011) and SIRT1 (Revilla et al., 2014). From the few studies to date that have examined exercise-induced effects on hippocampal neurogenesis in $A D$ mouse models, it is clear that neurogenic deficits can be effectively modulated by this intervention. Moreover, particularly in the $\mathrm{APP}_{\mathrm{SWE}} / \mathrm{PS}-1 \Delta \mathrm{E} 9$ mice, enhanced neurogenesis has been observed alongside cognitive improvements (Lin et al., 2015; Tapia-Rojas et al., 2016; Zhao et al., 2015), highlighting the key link between the two processes in the AD model of cognitive dysfunction. Assessments of hippocampal neurogenesis in addition to cognitive function in transgenic mouse models of AD given access to exercise would add greatly to our knowledge of the therapeutic or neuroprotective potential of physical activity in AD.

\subsection{Inflammation}

Exercise-mediated effects on inflammation have only been explored in a small number of studies with some mixed results emerging. Tapia-Rojas et al. (2016) report that ten weeks of voluntary wheel running reduced numbers of glial fibrillary acidic protein $(\mathrm{GFAP})^{+}$astrocytes in the hippocampus of $\mathrm{APP}_{\mathrm{SWE}} / \mathrm{PS}-1 \Delta \mathrm{E} 9$ mice. Five weeks of treadmill running was found to attenuate microglial activation in both adult and aged $\mathrm{APP}_{\text {SWE }} / \mathrm{PS}-1 \Delta \mathrm{E} 9$ mice (Ke et al., 2011). In contrast, other studies report no exerciseinduced effect on inflammation. Six weeks of wheel running had no effect on numbers of $\mathrm{GFAP}^{+}$astrocytes and Iba- $1^{+}$microglia in $\mathrm{APP}_{\mathrm{SWE}} / \mathrm{PS}-1 \Delta \mathrm{E} 9$ mice (Xu et al., 2013). Similarly, nine months of voluntary wheel running failed to alter the number of $\mathrm{GFAP}^{+}$ astrocytes and also had no effect on mRNA expression of IL-1 $\beta$, TNF- $\alpha$ and CD68 in the hippocampus of THY-Tau22 mice (Belarbi et al., 2011). Presently, the few studies in which inflammation has been examined and the mixed results which have been obtained make it difficult to draw solid conclusions about potential antiinflammatory effects of exercise.

\section{Optimum exercise conditions for maximal effect}

Although exercise-mediated effects vary dependent on mouse model, age, degree of pathology and modality of exercise, some interesting trends can be observed in Table 2 with respect to determining the optimum exercise strategies.

Both voluntary wheel running and treadmill running paradigms were successful in ameliorating AD pathology, reducing inflammation and mediating pro-cognitive and pro-neurogenic effects (Table 2). Beneficial effects were observed following just three weeks of voluntary wheel running (Nichol et al., 2007) up to nine months of wheel running (Belarbi et al., 2011). Exercising mice on treadmills also resulted in gains when mice were trained for five weeks (Ke et al., 2011) up to five months (Bo et al., 2014; Zhao et al., 2015). In general, however, treadmill exercise training programmes were typically three to five months in duration.

$A \beta$ plaque number (Liu et al., 2013), levels of $A \beta 40 / 42$ (Walker et al., 2015), tau phosphorylation (Um et al., 2011) and $p$-Tau ${ }^{+}$ cells (Tapia-Rojas et al., 2016) were all reduced following exercise (both voluntary and forced) across a number of models. However, it is also evident from certain studies that age (and thus degree of pathology) affects the ability of exercise to ameliorate some of the pathological features of AD. For instance, soluble $A \beta 42$ protein is reduced in eight and 17 month old $\mathrm{APP}_{\mathrm{SWE}} / \mathrm{PS}-1 \triangle \mathrm{E} 9$ mice following five months treadmill running, however, plaque number is only reduced in the eight month old mice (Zhao et al., 2015). Similarly, three weeks of voluntary wheel running did not ameliorate amyloid pathology in 15-19 month old Tg2576 mice (Parachikova et al., 2008). Moreover, ten days of wheel running reduced mRNA expression of $A \beta$ and APP but did not alleviate plaque load in 18 month old APP23 mice (Mirochnic et al., 2009). In contrast, A $\beta$ expression and plaque number, $p$-Tau expression, and BACE1 and C-terminal fragment (CTF) expression were all reduced in 27 month old triple transgenic mice following a 12 week treadmill running protocol (Cho et al., 2015). Thus it appears that for AD pathology at least, the age of the mouse and thus level of pathology must be considered when selecting an appropriate exercise regime for particular mouse models of $A D$, with maximal effects on AD pathology observed when exercise is initiated prior to the appearance of $A \beta$ plaques or at an early-mild stage of plaque deposition.

In contrast to $\mathrm{AD}$ pathology, pro-cognitive effects of exercise appear to be reproducible across animal models and occur largely independent of age. However, while learning and memory is improved in response to short and longer term exposure to running wheel, it appears that a longer training paradigm on the treadmill is required to mediate cognitive improvements. Xu et al. (2013) reported that six weeks of wheel running ( $2 \mathrm{~h}$ per day)by ten month old $\mathrm{APP}_{\mathrm{SWE}} / \mathrm{PS}-1 \Delta \mathrm{E} 9$ mice failed to ameliorate the performance of the mice in the MWW. In contrast, 17 month old mice of the same strain performed better in the MWM following five months of treadmill running (Zhao et al., 2015). Ke et al. (2011) reported that just five weeks of treadmill training improved performance of aged $\mathrm{APP}_{\mathrm{SWE}} / \mathrm{PS}-1 \Delta \mathrm{E} 9$ mice in the MWM, although no improvements were seen in younger adult mice and exercise did not improve aversive memory in the passive avoidance task at either age. In the Tg2576 model, recognition memory was rescued by 16 weeks of voluntary wheel running but not treadmill running (Yuede et al., 2009). The authors attribute this difference to different intensities between voluntary and forced running. Further studies with this mouse model are required to determine the most appropriate parameters for treadmill exercise.

As few studies have assessed exercise-induced alterations in hippocampal neurogenesis in mouse models of $\mathrm{AD}$, it is difficult to ascertain at this stage the most appropriate exercise intervention necessary to enhance hippocampal neurogenesis in the mouse models of AD. From the broader literature (i.e. non-AD focused) it is apparent that exercise-induced effects on hippocampal neurogenesis are robust and reproducible across species, age and exercise regime. Nonetheless, how the amyloid and tau pathology in the $\mathrm{AD}$ brain might influence exercise-induced effects is as yet unclear. 
Some conclusions may be drawn from the strong exercise-induced effects observed on cognition independent of age and pathological condition (Table 2). Given that hippocampal neurogenesis is believed to be necessary for gains in cognitive function, it could be proposed that the exercise-induced improvements reported to date are due to increased hippocampal neurogenesis, but this measure has simply not been assessed as of yet. Thus, as further studies are reported, it may emerge that hippocampal neurogenesis in mouse models of $\mathrm{AD}$ is amenable to exercise-induced alterations independent of mouse age, severity of pathology and exercise regime.

Only a few studies to date have assessed changes in neuroinflammatory markers following exercise in $\mathrm{AD}$ mice. Indeed, these studies have focused more on markers of astrogliosis; it is still unknown to what extent microgliosis and expression of proinflammatory cytokines, chemokines and other toxic species can be altered by exercise in AD mouse models. Thus far, Tapia-Rojas et al. (2016) report a reduction in $\mathrm{GFAP}^{+}$cells following ten weeks wheel running in five month old $\mathrm{APP}_{\mathrm{SWE}} / \mathrm{PS}-1 \Delta \mathrm{E} 9$ mice while Ke et al. (2011) observed reduced microglial activation in adult and aged mice following five weeks of treadmill running; Parachikova et al. (2008) demonstrated a reduction in mRNA expression of interleukin-11 (IL-11) and the chemokines chemokine ligand 1 (CXCL1) and chemokine ligand 12 (CXCL12) following three weeks of wheel running in 15-19 month old Tg2576 mice. In contrast, neither treadmill exercise nor wheel running reduced microglial and astrocyte activation along with pro-inflammatory cytokine mRNA expression in $\mathrm{APP}_{\mathrm{SWE}} / \mathrm{PS}-1 \Delta \mathrm{E} 9$ and THY-Tau22 mice respectively (Belarbi et al., 2011; Xu et al., 2013). To date, exercise-mediated effects have been observed in both young and aged mice. Further studies across all mouse models of AD are however necessary to strengthen our understanding of potential exercise-mediated effects on inflammation and how these effects may be influenced by gender, age and pathology progression in the various models before ascertaining whether regular exercise has promise as a non-pharmacological alternative to traditional anti-inflammatory interventions.

It is also worth considering at this junction the relevance of exercise interventions in mouse models of $A D$ and their role as preventative or curative strategies. From the studies presented in Table 2, significant evidence from the $\mathrm{APP}_{\mathrm{SWE}} / \mathrm{PS}-1 \Delta \mathrm{E} 9$ and Tg2576 mice supports exercise as a preventative intervention in the onset and development of $\mathrm{AD}$ pathology and cognitive decline. In the $\mathrm{APP}_{\text {SWE }} / \mathrm{PS}-1 \triangle \mathrm{E} 9$ mice, exercise which is initiated prior to or at the early stages of plaque formation, measures of AD pathology such as plaque number, $A \beta 42$ protein levels and $p$-Tau levels are all reduced along with improvements in cognitive function, when compared to non-exercising $\mathrm{APP}_{\mathrm{SWE}} / \mathrm{PS}-1 \Delta \mathrm{E} 9$ counterparts (Bo et al., 2014; Liu et al., 2013; Zhao et al., 2015). Other studies provide evidence for a curative effect of exercise. Training of 24 month old Tg-NSE/hPS-2 mice on a treadmill for three months was found to reduce hippocampal $A \beta 42$ protein and tau phosphorylation as well as improve performance of the mice in the MWM (Koo et al., 2013; Um et al., 2011). A number of other studies also provide evidence for exerciseinduced amelioration of cognitive function in mice in which $\mathrm{AD}$ pathology is deemed to be advanced but disappointingly have not included any data on exercise-induced alterations on typical AD pathologies (Marlatt et al., 2013; Rodriguez et al., 2011).

\section{Exercise in the clinic}

How do the data from animal models correspond to those from human studies of exercise in AD patients? Methodological limitations have largely restricted studies with humans and thus much of the data is related to exercised-induced effects on cognitive function. It is currently not possible to assess markers of AD pathology and hippocampal neurogenesis in live individuals. Moreover, studies to date have generally not assayed blood samples from AD patients and thus valuable information on the inflammatory profile of these individuals has been lost. Much of the evidence for a beneficial role of exercise in $\mathrm{AD}$ patients is associative in nature and based on self-reporting of physical activity levels by participants. Despite this shortcoming, it has been consistently reported that exercise is associated with a reduced risk of dementia and the level of reported physical activity correlates with the incidence of dementia across a number of studies (Andel et al., 2008; Buchman et al., 2012; Larson et al., 2006; Ravaglia et al., 2008). Randomised controlled trials, although few in number, also support exercise as a pro-cognitive intervention in individuals diagnosed with dementia (de Andrade et al., 2013; Kemoun et al., 2010; Van de Winckel et al., 2004; Venturelli et al., 2011; Vreugdenhil et al., 2012). Recently, Coelho et al. (2014) reported an increase in plasma BDNF levels in $\mathrm{AD}$ patients and healthy controls following a single bout of exercise on the treadmill, this result however was not accompanied by any cognitive testing. Also, recent neuroimaging data suggest that a 12 week moderate intensity walking intervention resulted in a thickening of the cortex, particularly in the left insula and superior temporal gyrus, in a cohort of patients displaying symptoms of mild cognitive impairment (Reiter et al., 2015). While these human studies give support to the data obtained from animal models, particularly with regard to exercise being a pro-cognitive intervention, future studies would undoubtedly benefit from adopting a multimodal approach and examine not only cognitive function, but also conduct neuroimaging to examine structural effects of exercise and biochemical analysis of blood samples to examine peripheral markers of inflammation and growth factors. Furthermore, the continuing expansion in the area of wearable technology and mobile monitoring of activity levels may give researchers a more accurate view of actual levels of physical activity of participants and enhance interpretation of results. This could also facilitate a greater number of physiological parameters to be recorded e.g. heart rate, blood pressure etc. thereby giving a better assessment of the degree of aerobic activity that is giving rise to alterations in cognitive performance. Although the focus of this review is on the benefits of physical activity in the context of $\mathrm{AD}$, it is also important to note other lifestyle interventions have also been examined in terms of reducing the risk of $\mathrm{AD}$ or delaying its onset. For instance, a number of nutrients have been reported to have pro-cognitive properties and dietary supplementation with such nutrients has been investigated to identify neuroprotective effects and potential for delaying the onset of AD (Dominguez and Barbagallo, 2016). There is also a growing literature examining the potential efficacy of cognitive stimulation and rehabilitation therapies. Further epidemiological evidence suggests reduced risk of dementia with individuals engaging in greater social activities and with individuals having higher levels of education (Gooding et al., 2015; Hampstead et al., 2014; Kelly, 2015; Lautenschlager et al., 2014; Quintana-Hernandez et al., 2015). Such studies highlight the growing importance which is being assigned to considering simple lifestyle interventions as nonpharmacological strategies to delay or slow down the onset and progression of $\mathrm{AD}$ and other dementias.

\section{Discussion}

Studies of exercise in mouse models of AD to date have demonstrated that exercise training is effective in altering AD pathology, cognitive function, hippocampal neurogenesis and inflammation (Fig. 1). Wheel running and treadmill training both prove effective methods of exercise, and indeed cognitive gains are observed in aged animals following just three weeks of exercise (Parachikova et al., 2008), however, reduction in $A \beta$ plaque number (along 
with cognitive and neurogenic gains) was only observed after ten weeks of running (Tapia-Rojas et al., 2016) and thus it appears that a minimum term of one month upwards of voluntary running should be considered to affect $A \beta$ pathology. Beyond this, there doesn't appear to be an upper limit for duration of voluntary running with reductions in $p$-Tau and improvements in spontaneous alternation observed following nine months of running (Belarbi et al., 2011). However, one must consider the intensity of exercise training when training durations are extended over a long term timecourse. Studies have reported mild rather than intensive training over a longer period to be pro-neurogenic and pro-cognitive (Inoue et al., 2015a,b) while also preventing over-activation of the hypothalamic-pituitary axis (Naylor et al., 2005). Conversely, treadmill training seems to require a longer training period, typically three months upwards to reduce $A \beta$ pathology and enhance cognitive function; changes in neurogenesis and inflammation remain to be probed further. Indeed there are still many questions to be answered on potential benefits of exercise, both in animal models of $\mathrm{AD}$ and also in human patients. The literature reviewed in this article has consistently demonstrated pro-cognitive effects of exercise and also the ability of amyloid pathology to be reduced. However, there is still no definitive recommendation emerging from preclinical studies which defines the optimum type, intensity and duration of exercise. Mice exercised on running wheels vs treadmills experience two very different exercise environments and this must be considered when comparing data from these two paradigms. Both wheel running and treadmill running have positive and negative attributes and neither modality can be considered more advantageous or 'correct' than the other. Firstly, mice generally travel greater distances when given access to a running wheel. Typically they run four-five km per day (Clark et al., 2009, 2008; Garrett et al., 2012; Patten et al., 2013; van Praag et al., 1999a) compared to mice on treadmills which typically run $280-700 \mathrm{~m}$ per day (Koo et al., 2013; Lin et al., 2015; Yuede et al., 2009; Zhao et al., 2015). Obviously, mice running on treadmills are unable to reach the distances that mice exercising voluntarily on a running wheel can achieve. This difference however poses the question of whether distance or regular exercise provides the greatest benefits. It is evident from the treadmill studies mentioned above that short regular bouts of exercise - typically 30-60 min duration, can alleviate AD pathology and enhance cognitive function. The bigger question is if short regular bouts of exercise are beneficial, then what intensity level should these sessions occur at? The majority of studies in Table 2 ran mice at a maximum speed of $10-12 \mathrm{~m} / \mathrm{min}$ for $30-60 \mathrm{~min}$ and reported improvements in $\mathrm{AD}$ pathology, cognitive function and neurogenesis. A recent study by Moore et al. (2015) adopted a high intensity approach with mice running up to $32 \mathrm{~m} / \mathrm{min}$ for $1 \mathrm{~h}$ with an incline. They reported that exercise reduced levels of hippocampal and cortical soluble $A \beta 40$ and $A \beta 42$ protein. Moreover the reduction was greater than mice who had only run at $15 \mathrm{~m} / \mathrm{min}$. While this study suggests that higher levels of exercise results in greater effects, the intensities at which the mice in this study exercised differs significantly from most other paradigms. Of more interest and translational value would be to look at the potential benefits of low intensity exercise that is roughly equivalent to walking speed. This would provide some information on the effectiveness of normal walking activity as an exercise intervention and could suggest significant health benefits of incorporating greater levels of walking into ones daily routine. Secondly, control mice are treated very differently dependent on the exercise paradigm adopted in a study. Sedentary mice in a wheel running study are generally housed in a standard homecage without a wheel whilst sedentary mice in a treadmill study are housed under the same conditions as the exercising mice and are also placed on a treadmill daily, however the treadmill remains stationary. It could be thus argued that sedentary mice in a treadmill study are not true controls as the mice are handled daily and experience the treadmill environment daily also. Conversely, the validity of the control sedentary mouse in the standard homecage must also be considered - how relevant is the non-stimulating homecage environment in which they are housed? How does a sedentary mouse housed in a standard homecage translate to a sedentary human individual?

Future studies need to extend the focus beyond simply assessing exercise-induced effects on $\mathrm{AD}$ pathology and cognitive function in mouse models of AD. For example, exercise-induced effects on hippocampal neurogenesis are beginning to be explored in greater detail in AD mouse models. It must be determined whether neurogenic deficits in $A D$ are a result of a reduction in the NSC pool and its proliferation, neuronal differentiation or maturation and integration of these new neurons into existing circuitry, and which of these processes exercise can mediate effects on. Similarly, the scope of exercise-mediated effects on neuroinflammation in $\mathrm{AD}$ mouse models is research in its infancy. Whether exercise can modulate microglial activation, function and phagocytic abilities, as well as secretion of pro- and anti-inflammatory cytokines, chemokines and other toxic species remains to be investigated in greater detail. Consideration must also be given to ways in which exercise can indirectly affect hippocampal neurogenesis and inflammation. For example, Wrann et al. (2013) reported that 30 days of wheel running increased mRNA expression of Peroxisome proliferator-activated receptor gamma coactivator 1-alpha (PGC-1 $\alpha)$ and Fibronectin type III domain-containing protein 5 (FNDC5) in both skeletal muscle and the hippocampus and also observed the typical exercise-induced upregulation of hippocampal BDNF mRNA. They further demonstrated that overexpression of FNDC5 in cortical neuron cultures increased BDNF mRNA while RNAi-mediated knockdown of FNDC5 reduced BDNF mRNA (Wrann et al., 2013). These data identify a link between exercise-mediated effects in both the periphery and CNS. Further studies will no doubt uncover additional mechanisms by which exercise-mediated effects on neurogenesis occur and further enhance our understanding of crosstalk between the periphery and the CNS. Exercise also induces a host of effects across many systems such as effects on body fat, metabolic activity, cardiac and skeletal muscle function. All of these processes involve the peripheral immune system to some degree e.g. increasing IL-6 release from contracting muscle (Fischer, 2006)and switching the inflammatory profile from a largely pro-inflammatory in the case of adipose tissue expansion in non-exercising subjects to a more anti-inflammatory profile in individuals partaking in regular exercise (Gleeson et al., 2011; Yudkin, 2007). Whether these changes observed in the peripheral immune system can influence changes in the neuroinflammatory context remains to be probed further.

Furthermore one of the greatest unknowns remains the question of persistence of exercise-induced effects. Preclinical studies most often assess cognitive performance and carry out postmortem tissue analyses immediately following cessation of exercise training thus there are many questions to be answered in this regard. Studies have shown that exercise commenced at an advanced age and following disease onset can alleviate some of the disease symptoms. However, in what way would this intervention compare to exercise training initiated at a younger age prior to disease onset? Recently Clemente Motta-Teixeira et al. (2015) reported that the survival of new neurons in the adult rat DG decreased significantly when the time delay between cessation of wheel running and analysis of neuronal survival was increased. The protocol employed in this study examined neuronal survival up to six weeks after cessation of housing of the rats with running wheels for one week. Further studies are required to explore longer duration running periods as well as extending the delay between exercise cessation 
and cognitive testing and postmortem analyses as well as extending this strategy to mouse models of disease, such as AD.

\section{Conclusion}

There is now a growing body of evidence from the literature which highlights the contribution of exercise to ameliorating AD pathology, improving cognitive performance, enhancing adult hippocampal neurogenesis and reducing neuroinflammation in transgenic mouse models AD. Questions still remain surrounding key issues such as the optimum time to start exercise and the intensity at which such interventions should be undertaken. It is also important to bear in mind the relevance of such studies and their translation to the human population, in particular when comparing sedentary mice to sedentary humans. Despite the many questions that remain to be debated, preclinical studies provide a strong basis for the consideration of adopting exercise as a non-pharmacological intervention in the human AD population.

\section{Acknowledgements}

This research was funded by an Irish Research Council Government of Ireland Postdoctoral Fellowship.

\section{References}

Adlard, P.A., Perreau, V.M., Pop, V., Cotman, C.W., 2005. Voluntary exercise decreases amyloid load in a transgenic model of Alzheimer's disease. J. Neurosci. 25, 4217-4221

Adlard, P.A., Bica, L., White, A.R., Nurjono, M., Filiz, G., Crouch, P.J., Donnelly, P.S., Cappai, R., Finkelstein, D.I., Bush, A.I., 2011. Metal ionophore treatment restores dendritic spine density and synaptic protein levels in a mouse model of Alzheimer's disease. PLoS One 6, e17669.

Adzovic, L., Lynn, A.E., D’Angelo, H.M., Crockett, A.M., Kaercher, R.M., Royer, S.E., Hopp, S.C., Wenk, G.L., 2015. Insulin improves memory and reduces chronic neuroinflammation in the hippocampus of young but not aged brains. J. Neuroinflammation 12,63.

Altman, J., 1962. Are new neurons formed in the brains of adult mammals? Science 135, 1127-1128.

Andel, R., Crowe, M., Pedersen, N.L., Fratiglioni, L., Johansson, B., Gatz, M., 2008. Physical exercise at midlife and risk of dementia three decades later: population-based study of Swedish twins. J. Gerontol. Ser. A Biol. Sci. Med. Sci. 63, 62-66.

Arendash, G.W., Garcia, M.F., Costa, D.A., Cracchiolo, J.R., Wefes, I.M., Potter, H. 2004. Environmental enrichment improves cognition in aged Alzheimer's transgenic mice despite stable beta-amyloid deposition. Neuroreport 15 1751-1754.

Bachstetter, A.D., Norris, C.M., Sompol, P., Wilcock, D.M., Goulding, D., Neltner, J.H., St Clair, D., Watterson, D.M., Van Eldik, L.J., 2012. Early stage drug treatment that normalizes proinflammatory cytokine production attenuates synaptic dysfunction in a mouse model that exhibits age-dependent progression of Alzheimer's disease-related pathology. J. Neurosci. 32, 10201-10210.

Belarbi, K., Burnouf, S., Fernandez-Gomez, F.J., Laurent, C., Lestavel, S., Figeac, M., Sultan, A., Troquier, L., Leboucher, A., Caillierez, R., Grosjean, M.E., Demeyer, D., Obriot, H., Brion, I., Barbot, B., Galas, M.C., Staels, B., Humez, S., Sergeant, N., Schraen-Maschke, S., Muhr-Tailleux, A., Hamdane, M., Buee, L., Blum, D., 2011. Beneficial effects of exercise in a transgenic mouse model of Alzheimer's disease-like Tau pathology. Neurobiol. Dis. 43, 486-494.

Ben Menachem-Zidon, O., Goshen, I., Kreisel, T., Ben Menahem, Y., Reinhartz, E., Ben Hur, T., Yirmiya, R., 2008. Intrahippocampal transplantation of transgenic neural precursor cells overexpressing interleukin-1 receptor antagonist blocks chronic isolation-induced impairment in memory and neurogenesis. Neuropsychopharmacology 33, 2251-2262

Ben-Menachem-Zidon, O., Ben-Menahem, Y., Ben-Hur, T., Yirmiya, R., 2014. Intra-hippocampal transplantation of neural precursor cells with transgenic over-expression of IL-1 receptor antagonist rescues memory and neurogenesis impairments in an Alzheimer's disease model. Neuropsychopharmacology 39, 401-414.

Bhattacharya, T.K., Pence, B.D., Ossyra, J.M., Gibbons, T.E., Perez, S., McCusker, R.H. Kelley, K.W., Johnson, R.W., Woods, J.A., Rhodes, J.S., 2015. Exercise but not (-)-epigallocatechin-3-gallate or beta-alanine enhances physical fitness, brain plasticity, and behavioral performance in mice. Physiol. Behav. 145, 29-37.

Biscaro, B., Lindvall, O., Tesco, G., Ekdahl, C.T., Nitsch, R.M., 2012. Inhibition of microglial activation protects hippocampal neurogenesis and improves cognitive deficits in a transgenic mouse model for Alzheimer's disease. Neuro-degener. Dis. 9, 187-198.
Black, J.E., Isaacs, K.R., Anderson, B.J., Alcantara, A.A., Greenough, W.T., 1990. Learning causes synaptogenesis, whereas motor activity causes angiogenesis, in cerebellar cortex of adult rats. Proc. Natl. Acad. Sci. U. S. A. 87, 5568-5572.

Blanchard, J., Wanka, L., Tung, Y.C., Cardenas-Aguayo Mdel, C., LaFerla, F.M., Iqbal, K., Grundke-Iqbal, I., 2010. Pharmacologic reversal of neurogenic and neuroplastic abnormalities and cognitive impairments without affecting Abeta and tau pathologies in 3xTg-aD mice. Acta Neuropathol. (Berl.) 120, 605-621.

Bo, H., Kang, W., Jiang, N., Wang, X., Zhang, Y., Ji, L.L., 2014. Exercise-induced neuroprotection of hippocampus in APP/PS1 transgenic mice via upregulation of mitochondrial 8-oxoguanine DNA glycosylase. Oxid. Med. Cell. Longev. 2014, 834502

Boehme, M., Guenther, M., Stahr, A., Liebmann, M., Jaenisch, N., Witte, O.W., Frahm, C., 2014. Impact of indomethacin on neuroinflammation and hippocampal neurogenesis in aged mice. Neurosci. Lett. 572, 7-12.

Boekhoorn, K., Joels, M., Lucassen, P.J., 2006. Increased proliferation reflects glial and vascular-associated changes, but not neurogenesis in the presenile Alzheimer hippocampus. Neurobiol. Dis. 24, 1-14.

Boldrini, M., Hen, R., Underwood, M.D., Rosoklija, G.B., Dwork, A.J., Mann, J.J., Arango, V., 2012. Hippocampal angiogenesis and progenitor cell proliferation are increased with antidepressant use in major depression. Biol. Psychiatry 72, 562-571.

Bolognin, S., Buffelli, M., Puolivali, J., Iqbal, K., 2014. Rescue of cognitive-aging by administration of a neurogenic and/or neurotrophic compound. Neurobiol. Aging 35, 2134-2146.

Borchelt, D.R., Ratovitski, T., van Lare, J., Lee, M.K., Gonzales, V., Jenkins, N.A., Copeland, N.G., Price, D.L., Sisodia, S.S., 1997. Accelerated amyloid deposition in the brains of transgenic mice coexpressing mutant presenilin 1 and amyloid precursor proteins. Neuron 19, 939-945.

Braak, H., Braak, E., 1991. Neuropathological stageing of Alzheimer-related changes. Acta Neuropathol. (Berl.) 82, 239-259.

Brandt, M.D., Maass, A., Kempermann, G., Storch, A., 2010. Physical exercise increases Notch activity, proliferation and cell cycle exit of type-3 progenitor cells in adult hippocampal neurogenesis. Eur. J. Neurosci. 32, 1256-1264.

Bruel-Jungerman, E., Veyrac, A., Dufour, F., Horwood, J., Laroche, S., Davis, S., 2009. Inhibition of PI3K-Akt signaling blocks exercise-mediated enhancement of adult neurogenesis and synaptic plasticity in the dentate gyrus. PLoS One 4 e7901.

Brus, M., Keller, M., Levy, F., 2013. Temporal features of adult neurogenesis: differences and similarities across mammalian species. Front. Neurosci. 7, 135.

Buchman, A.S., Boyle, P.A., Yu, L., Shah, R.C., Wilson, R.S., Bennett, D.A., 2012. Total daily physical activity and the risk of AD and cognitive decline in older adults. Neurology 78, 1323-1329.

Chang, Y.T., Chen, Y.C., Wu, C.W., Yu, L., Chen, H.I., Jen, C.J., Kuo, Y.M., 2008. Glucocorticoid signaling and exercise-induced downregulation of the mineralocorticoid receptor in the induction of adult mouse dentate neurogenesis by treadmill running. Psychoneuroendocrinology 33, 1173-1182

Chishti, M.A., Yang, D.S., Janus, C., Phinney, A.L., Horne, P., Pearson, J., Strome, R., Zuker, N., Loukides, J., French, J., Turner, S., Lozza, G., Grilli, M., Kunicki, S., Morissette, C., Paquette, J., Gervais, F., Bergeron, C., Fraser, P.E., Carlson, G.A., George-Hyslop, P.S., Westaway, D., 2001. Early-onset amyloid deposition and cognitive deficits in transgenic mice expressing a double mutant form of amyloid precursor protein 695. J. Biol. Chem. 276, 21562-21570.

Cho, J.Y., Hwang, D.Y., Kang, T.S., Shin, D.H., Hwang, J.H., Lim, C.H., Lee, S.H., Lim, H.J., Min, S.H., Seo, S.J., Song, Y.S., Nam, K.T., Lee, K.S., Cho, J.S., Kim, Y.K., 2003. Use of NSE/PS2m-transgenic mice in the study of the protective effect of exercise on Alzheimer's disease. J. Sports Sci. 21, 943-951.

Cho, J., Shin, M.K., Kim, D., Lee, I., Kim, S., Kang, H., 2015. Treadmill running reverses cognitive declines due to Alzheimer disease. Med. Sci. Sports Exerc. 47, 1814-1824.

Choi, M.L., Begeti, F., Oh, J.H., Lee, S.Y., O'Keeffe, G.C., Clelland, C.D., Tyers, P., Cho, Z.H., Kim, Y.B., Barker, R.A., 2014a. Dopaminergic manipulations and its effects on neurogenesis and motor function in a transgenic mouse model of Huntington's disease. Neurobiol. Dis. 66, 19-27.

Choi, Y., Lee, K., Ryu, J., Kim, H.G., Jeong, A.Y., Woo, R.S., Lee, J.H., Hyun, J.W., Hahn, S., Kim, J.H., Kim, H.S., 2014b. Neuritin attenuates cognitive function impairments in tg2576 mouse model of Alzheimer's disease. PLoS One 9, e104121.

Clark, P.J., Brzezinska, W.J., Thomas, M.W., Ryzhenko, N.A., Toshkov, S.A., Rhodes, J.S., 2008. Intact neurogenesis is required for benefits of exercise on spatial memory but not motor performance or contextual fear conditioning in C57BL/6J mice. Neuroscience 155, 1048-1058.

Clark, P.J., Brzezinska, W.J., Puchalski, E.K., Krone, D.A., Rhodes, J.S., 2009. Functional analysis of neurovascular adaptations to exercise in the dentate gyrus of young adult mice associated with cognitive gain. Hippocampus 19, 937-950

Clemente Motta-Teixeira, L., Takada, S.H., Machado-Nils, A.V., Nogueira, M.I., Xavier, G.F., 2015. Spatial learning and neurogenesis: effects of cessation of wheel running and survival of novel neurons by engagement in cognitive tasks. Hippocampus, http://dx.doi.org/10.1002/hipo.22560.

Coelho, F.G., Vital, T.M., Stein, A.M., Arantes, F.J., Rueda, A.V., Camarini, R. Teodorov, E., Santos-Galduroz, R.F., 2014. Acute aerobic exercise increases brain-derived neurotrophic factor levels in elderly with Alzheimer's disease. J. Alzheimers Dis. 39, 401-408.

Crews, L., Adame, A., Patrick, C., Delaney, A., Pham, E., Rockenstein, E., Hansen, L., Masliah, E., 2010. Increased BMP6 levels in the brains of Alzheimer's disease patients and APP transgenic mice are accompanied by impaired neurogenesis. J. Neurosci. 30, 12252-12262. 
Cribbs, D.H., Berchtold, N.C., Perreau, V., Coleman, P.D., Rogers, J., Tenner, A.J., Cotman, C.W., 2012. Extensive innate immune gene activation accompanies brain aging, increasing vulnerability to cognitive decline and neurodegeneration: a microarray study. J. Neuroinflammation 9, 179.

Curlik 2nd, D.M., Shors, T.J., 2011. Learning increases the survival of newborn neurons provided that learning is difficult to achieve and successful. J. Cogn. Neurosci. 23, 2159-2170.

D’Alessio, L., Konopka, H., Escobar, E., Acuna, A., Oddo, S., Solis, P., Seoane, E., Kochen, S., 2015. Dentate gyrus expression of nestin-immunoreactivity in patients with drug-resistant temporal lobe epilepsy and hippocampal sclerosis. Seizure 27, 75-79.

Demars, M., Hu, Y.S., Gadadhar, A., Lazarov, O., 2010. Impaired neurogenesis is an early event in the etiology of familial Alzheimer's disease in transgenic mice. J. Neurosci. Res. 88, 2103-2117.

Dinel, A.L., Joffre, C., Trifilieff, P., Aubert, A., Foury, A., Le Ruyet, P., Laye, S., 2014. Inflammation early in life is a vulnerability factor for emotional behavior at adolescence and for lipopolysaccharide-induced spatial memory and neurogenesis alteration at adulthood. J. Neuroinflammation 11, 155

Dominguez, L.J., Barbagallo, M., 2016. Dietary approaches and supplements in the prevention of cognitive decline and Alzheimer's disease. Curr. Pharm. Des. 22, $688-700$.

Donovan, M.H., Yazdani, U., Norris, R.D., Games, D., German, D.C., Eisch, A.J., 2006. Decreased adult hippocampal neurogenesis in the PDAPP mouse model of Alzheimer's disease. J. Comp. Neurol. 495, 70-83.

Dupret, D., Revest, J.M., Koehl, M., Ichas, F., De Giorgi, F., Costet, P., Abrous, D.N., Piazza, P.V., 2008. Spatial relational memory requires hippocampal adult neurogenesis. PLoS One 3, e1959.

Ekdahl, C.T., Claasen, J.-H., Bonde, S., Kokaia, Z., Lindvall, O., 2003. Inflammation is detrimental for neurogenesis in adult brain. Proc. Natl. Acad. Sci. U.S.A. 100, 13632-13637.

Ermini, F.V., Grathwohl, S., Radde, R., Yamaguchi, M., Staufenbiel, M., Palmer, T.D. Jucker, M., 2008. Neurogenesis and alterations of neural stem cells in mouse models of cerebral amyloidosis. Am. J. Pathol. 172, 1520-1528.

Farioli-Vecchioli, S., Saraulli, D., Costanzi, M., Pacioni, S., Cina, I., Aceti, M., Micheli L., Bacci, A., Cestari, V., Tirone, F., 2008. The timing of differentiation of adult hippocampal neurons is crucial for spatial memory. PLoS Biol. 6, e246.

Ferreira, A.F., Real, C.C., Rodrigues, A.C., Alves, A.S., Britto, L.R., 2011. Short-term, moderate exercise is capable of inducing structural, BDNF-independent hippocampal plasticity. Brain Res. 1425, 111-122.

Fischer, C.P., 2006. Interleukin-6 in acute exercise and training: what is the biological relevance? Exerc. Immunol. Rev. 12, 6-33.

Fuster-Matanzo, A., de Barreda, E.G., Dawson, H.N., Vitek, M.P., Avila, J., Hernandez, F., 2009. Function of tau protein in adult newborn neurons. FEBS Lett. 583, 3063-3068.

Fuster-Matanzo, A., Llorens-Martin, M., Jurado-Arjona, J., Avila, J., Hernandez, F., 2012. Tau protein and adult hippocampal neurogenesis. Front. Neurosci. 6, 104.

Games, D., Adams, D., Alessandrini, R., Barbour, R., Berthelette, P., Blackwell, C., Carr, T., Clemens, J., Donaldson, T., Gillespie, F., et al., 1995. Alzheimer-type neuropathology in transgenic mice overexpressing V717F beta-amyloid precursor protein. Nature 373, 523-527.

Garcia-Mesa, Y., Gimenez-Llort, L., Lopez, L.C., Venegas, C., Cristofol, R., Escames, G., Acuna-Castroviejo, D., Sanfeliu, C., 2012. Melatonin plus physical exercise are highly neuroprotective in the 3xTg-AD mouse. Neurobiol. Aging 33 (1124), e1113-1129.

Garrett, L., Lie, D.C., Hrabe de Angelis, M., Wurst, W., Holter, S.M., 2012. Voluntary wheel running in mice increases the rate of neurogenesis without affecting anxiety-related behaviour in single tests. BMC Neurosci. 13, 61.

Ghosh, S., Wu, M.D., Shaftel, S.S., Kyrkanides, S., LaFerla, F.M., Olschowka, J.A., O'Banion, M.K., 2013. Sustained interleukin-1beta overexpression exacerbates tau pathology despite reduced amyloid burden in an Alzheimer's mouse model. J. Neurosci. 33, 5053-5064.

Gibbons, T.E., Pence, B.D., Petr, G., Ossyra, J.M., Mach, H.C., Bhattacharya, T.K., Perez, S., Martin, S.A., McCusker, R.H., Kelley, K.W., Rhodes, J.S., Johnson, R.W., Woods, J.A., 2014. Voluntary wheel running, but not a diet containing (-)-epigallocatechin-3-gallate and beta-alanine, improves learning, memory and hippocampal neurogenesis in aged mice. Behav. Brain Res. 272, 131-140.

Glasper, E.R., Llorens-Martin, M.V., Leuner, B., Gould, E., Trejo, J.L., 2010. Blockade of insulin-like growth factor-I has complex effects on structural plasticity in the hippocampus. Hippocampus 20, 706-712.

Gleeson, M., Bishop, N.C., Stensel, D.J., Lindley, M.R., Mastana, S.S., Nimmo, M.A 2011. The anti-inflammatory effects of exercise: mechanisms and implications for the prevention and treatment of disease. Nat. Rev. Immunol. 11, 607-615.

Gooding, A.L., Choi, J., Fiszdon, J.M., Wilkins, K., Kirwin, P.D., van Dyck, C.H., Devanand, D., Bell, M.D., Rivera Mindt, M., 2015. Comparing three methods of computerised cognitive training for older adults with subclinical cognitive decline. Neuropsychol. Rehabil., 1-12.

Goodman, T., Trouche, S., Massou, I., Verret, L., Zerwas, M., Roullet, P., Rampon, C. 2010. Young hippocampal neurons are critical for recent and remote spatial memory in adult mice. Neuroscience 171, 769-778

Griffin, E.W., Bechara, R.G., Birch, A.M., Kelly, A.M., 2009. Exercise enhances hippocampal-dependent learning in the rat: evidence for a BDNF-related mechanism. Hippocampus 19, 973-980.

Hamilton, L.K., Aumont, A., Julien, C., Vadnais, A., Calon, F., Fernandes, K.J., 2010. Widespread deficits in adult neurogenesis precede plaque and tangle formation in the 3xTg mouse model of Alzheimer's disease. Eur. J. Neurosci. 32, 905-920.
Hampstead, B.M., Mosti, C.B., Swirsky-Sacchetti, T., 2014. Cognitively-based methods of enhancing and maintaining functioning in those at risk of Alzheimer's disease. J. Alzheimers Dis, 42 (Suppl. 4), S483-493.

Hein, A.M., Stasko, M.R., Matousek, S.B., Scott-McKean, J.J., Maier, S.F., Olschowka, J.A., Costa, A.C., O’Banion, M.K., 2010. Sustained hippocampal IL-1beta overexpression impairs contextual and spatial memory in transgenic mice. Brain Behav. Immun. 24, 243-253.

Heine, V.M., Maslam, S., Joels, M., Lucassen, P.J., 2004. Prominent decline of newborn cell proliferation, differentiation, and apoptosis in the aging dentate gyrus, in absence of an age-related hypothalamus-pituitary-adrenal axis activation. Neurobiol. Aging 25, 361-375.

Heneka, M.T., Carson, M.J., El Khoury, J., Landreth, G.E., Brosseron, F., Feinstein, D.L., Jacobs, A.H., Wyss-Coray, T., Vitorica, J., Ransohoff, R.M., Herrup, K., Frautschy, S.A., Finsen, B., Brown, G.C., Verkhratsky, A., Yamanaka, K., Koistinaho, J., Latz, E., Halle, A., Petzold, G.C., Town, T., Morgan, D., Shinohara, M.L., Perry, V.H., Holmes, C., Bazan, N.G., Brooks, D.J., Hunot, S., Joseph, B., Deigendesch, N., Garaschuk, O., Boddeke, E., Dinarello, C.A., Breitner, J.C., Cole, G.M., Golenbock, D.T., Kummer, M.P., 2015. Neuroinflammation in Alzheimer's disease. Lancet Neurol. 14, 388-405.

Heppner, F.L., Ransohoff, R.M., Becher, B., 2015. Immune attack: the role of inflammation in Alzheimer disease. Nat. Rev. Neurosci. 16, 358-372.

Hickman, S.E., Allison, E.K., El Khoury, J., 2008. Microglial dysfunction and defective beta-amyloid clearance pathways in aging Alzheimer's disease mice. J. Neurosci. 28, 8354-8360.

Holcomb, L., Gordon, M.N., McGowan, E., Yu, X., Benkovic, S., Jantzen, P., Wright, K. Saad, I., Mueller, R., Morgan, D., Sanders, S., Zehr, C., O’Campo, K., Hardy, J., Prada, C.M., Eckman, C., Younkin, S., Hsiao, K., Duff, K., 1998. Accelerated Alzheimer-type phenotype in transgenic mice carrying both mutant amyloid precursor protein and presenilin 1 transgenes. Nat. Med. 4, 97-100.

Hong, X.P., Peng, C.X., Wei, W., Tian, Q., Liu, Y.H., Yao, X.Q., Zhang, Y., Cao, F.Y., Wang, Q., Wang, J.Z., 2010. Essential role of tau phosphorylation in adult hippocampal neurogenesis. Hippocampus 20, 1339-1349.

Hsia, A.Y., Masliah, E., McConlogue, L., Yu, G.Q., Tatsuno, G., Hu, K., Kholodenko, D., Malenka, R.C., Nicoll, R.A., Mucke, L., 1999. Plaque-independent disruption of neural circuits in Alzheimer's disease mouse models. Proc. Natl. Acad. Sci. U. S. A. 96, 3228-3233

Hsiao, K., Chapman, P., Nilsen, S., Eckman, C., Harigaya, Y., Younkin, S., Yang, F. Cole, G., 1996. Correlative memory deficits, abeta elevation, and amyloid plaques in transgenic mice. Science 274, 99-102.

http://www.worldalzreport2015, org/2015.

Hwang, D.Y., Chae, K.R., Kang, T.S., Hwang, J.H., Lim, C.H., Kang, H.K., Goo, J.S., Lee, M.R., Lim, H.J., Min, S.H., Cho, J.Y., Hong, J.T., Song, C.W., Paik, S.G., Cho, J.S., Kim, Y.K., 2002. Alterations in behavior amyloid beta-42, caspase-3, and Cox-2 in mutant PS2 transgenic mouse model of Alzheimer's disease. FASEB J. 16, 805-813.

Iascone, D.M., Padidam, S., Pyfer, M.S., Zhang, X., Zhao, L., Chin, J., 2013. Impairments in neurogenesis are not tightly linked to depressive behavior in a transgenic mouse model of Alzheimer's disease. PLoS One 8, e79651.

Imbimbo, B.P., Giardino, L., Sivilia, S., Giuliani, A., Gusciglio, M., Pietrini, V., Del Giudice, E., D’Arrigo, A., Leon, A., Villetti, G., Calza, L., 2010. CHF5074, a novel gamma-secretase modulator, restores hippocampal neurogenesis potential and reverses contextual memory deficit in a transgenic mouse model of Alzheimer's disease. J. Alzheimers Dis. 20, 159-173.

Inoue, K., Hanaoka, Y., Nishijima, T., Okamoto, M., Chang, H., Saito, T., Soya, H., 2015a. Long-term mild exercise training enhances hippocampus-dependent memory in rats. Int. J. Sports Med. 36, 280-285.

Inoue, K., Okamoto, M., Shibato, J., Lee, M.C., Matsui, T., Rakwal, R., Soya, H., 2015b. Long-term mild, rather than intense, exercise enhances adult hippocampal neurogenesis and greatly changes the transcriptomic profile of the hippocampus. PLoS One 10, e0128720.

Jankowsky, J.L., Xu, G., Fromholt, D., Gonzales, V., Borchelt, D.R., 2003. Environmental enrichment exacerbates amyloid plaque formation in a transgenic mouse model of Alzheimer disease. J. Neuropathol. Exp. Neurol. 62, 1220-1227

Jin, K., Galvan, V., Xie, L., Mao, X.O., Gorostiza, O.F., Bredesen, D.E., Greenberg, D.A., 2004a. Enhanced neurogenesis in Alzheimer's disease transgenic (PDGF-APPSw,Ind) mice. Proc. Natl. Acad. Sci. U. S. A. 101, 13363-13367.

Jin, K., Peel, A.L., Mao, X.O., Xie, L., Cottrell, B.A., Henshall, D.C., Greenberg, D.A., 2004b. Increased hippocampal neurogenesis in Alzheimer's disease. Proc. Natl. Acad. Sci. U. S. A. 101, 343-347.

Johansson, J.U., Woodling, N.S., Wang, Q., Panchal, M., Liang, X., Trueba-Saiz, A. Brown, H.D., Mhatre, S.D., Loui, T., Andreasson, K.I., 2015. Prostaglandin signaling suppresses beneficial microglial function in Alzheimer's disease models. J. Clin. Invest. 125, 350-364.

Kalra, J., Khan, A., 2015. Reducing Abeta load and tau phosphorylation: emerging perspective for treating Alzheimer's disease. Eur. J. Pharmacol. 764, 571-581.

Kang, W., Hebert, J.M., 2015. FGF signaling is necessary for neurogenesis in young mice and sufficient to reverse its decline in old mice. J. Neurosci. 35 , 10217-10223.

Ke, H.C., Huang, H.J., Liang, K.C., Hsieh-Li, H.M., 2011. Selective improvement of cognitive function in adult and aged APP/PS1 transgenic mice by continuous non-shock treadmill exercise. Brain Res. 1403, 1-11.

Kelly, A.M., 2015. Non-pharmacological approaches to cognitive enhancement. Handb. Exp. Pharmacol. 228, 417-439.

Kemoun, G., Thibaud, M., Roumagne, N., Carette, P., Albinet, C., Toussaint, L., Paccalin, M., Dugue, B., 2010. Effects of a physical training programme on 
cognitive function and walking efficiency in elderly persons with dementia. Dement. Geriatr. Cogn. Disord. 29, 109-114.

Kempermann, G., Kuhn, H.G., Gage, F.H., 1997. More hippocampal neurons in adult mice living in an enriched environment. Nature 386, 493-495.

Kiyota, T., Okuyama, S., Swan, R.J., Jacobsen, M.T., Gendelman, H.E., Ikezu, T., 2010. CNS expression of anti-inflammatory cytokine interleukin-4 attenuates Alzheimer's disease-like pathogenesis in APP + PS1 bigenic mice. FASEB J. 24 3093-3102.

Kobilo, T., Liu, Q.R., Gandhi, K., Mughal, M., Shaham, Y., van Praag, H., 2011. Running is the neurogenic and neurotrophic stimulus in environmental enrichment. Learn. Mem. 18, 605-609.

Kohman, R.A., Rhodes, J.S., 2013. Neurogenesis, inflammation and behavior. Brain Behav. Immun. 27, 22-32.

Komuro, Y., Xu, G., Bhaskar, K., Lamb, B.T., 2015. Human tau expression reduces adult neurogenesis in a mouse model of tauopathy. Neurobiol. Aging 36 2034-2042.

Koo, J.W., Duman, R.S., 2008. IL-1beta is an essential mediator of the antineurogenic and anhedonic effects of stress. Proc. Natl. Acad. Sci. U. S. A. 105, 751-756.

Koo, J.H., Kwon, I.S., Kang, E.B., Lee, C.K., Lee, N.H., Kwon, M.G., Cho, I.H., Cho, J.Y., 2013. Neuroprotective effects of treadmill exercise on BDNF and PI3-K/Akt signaling pathway in the cortex of transgenic mice model of Alzheimer's disease. J. Exerc. Nutr. Biochem. 17, 151-160

Krezymon, A., Richetin, K., Halley, H., Roybon, L., Lassalle, J.M., Frances, B., Verret, L., Rampon, C., 2013. Modifications of hippocampal circuits and early disruption of adult neurogenesis in the tg2576 mouse model of Alzheimer's disease. PLoS One 8, e76497.

Kronenberg, G., Bick-Sander, A., Bunk, E., Wolf, C., Ehninger, D., Kempermann, G. 2006. Physical exercise prevents age-related decline in precursor cell activity in the mouse dentate gyrus. Neurobiol. Aging 27, 1505-1513.

Krstic, D., Madhusudan, A., Doehner, J., Vogel, P., Notter, T., Imhof, C., Manalastas, A., Hilfiker, M., Pfister, S., Schwerdel, C., Riether, C., Meyer, U., Knuesel, I., 2012. Systemic immune challenges trigger and drive Alzheimer-like neuropathology in mice. J. Neuroinflammation 9, 151

Kuhn, H.G., Dickinson-Anson, H., Gage, F.H., 1996. Neurogenesis in the dentate gyrus of the adult rat: age-related decrease of neuronal progenitor proliferation. J. Neurosci. 16, 2027-2033.

Larson, E.B., Wang, L., Bowen, J.D., McCormick, W.C., Teri, L., Crane, P., Kukull, W. 2006. Exercise is associated with reduced risk for incident dementia among persons 65 years of age and older. Ann. Intern. Med. 144, 73-81.

Lautenschlager, N.T., Anstey, K.J., Kurz, A.F., 2014. Non-pharmacological strategies to delay cognitive decline. Maturitas 79, 170-173.

Lazarov, O., Robinson, J., Tang, Y.P., Hairston, I.S., Korade-Mirnics, Z., Lee, V.M. Hersh, L.B., Sapolsky, R.M., Mirnics, K., Sisodia, S.S., 2005. Environmental enrichment reduces abeta levels and amyloid deposition in transgenic mice. Cell 120, 701-713.

Li, F., Dong, H.X., Gong, Q.H., Wu, Q., Jin, F., Shi, J.S., 2015. Icariin decreases both APP and Abeta levels and increases neurogenesis in the brain of Tg2576 mice. Neuroscience 304, 29-35.

Lin, T.W., Shih, Y.H., Chen, S.J., Lien, C.H., Chang, C.Y., Huang, T.Y., Chen, S.H., Jen, C.J., Kuo, Y.M., 2015. Running exercise delays neurodegeneration in amygdala and hippocampus of Alzheimer's disease (APP/PS1) transgenic mice. Neurobiol. Learn. Mem. 118, 189-197.

Liu, H.L., Zhao, G., Cai, K., Zhao, H.H., Shi, L.D., 2011. Treadmill exercise prevents decline in spatial learning and memory in APP/PS1 transgenic mice through improvement of hippocampal long-term potentiation. Behav. Brain Res. 218 308-314

Liu, H.L., Zhao, G., Zhang, H., Shi, L.D., 2013. Long-term treadmill exercise inhibits the progression of Alzheimer's disease-like neuropathology in the hippocampus of APP/PS1 transgenic mice. Behav. Brain Res. 256, 261-272.

Llorens-Martin, M., Jurado-Arjona, J., Fuster-Matanzo, A., Hernandez, F., Rabano, A Avila, J., 2014. Peripherally triggered and GSK-3beta-driven brain inflammation differentially skew adult hippocampal neurogenesis, behavioral pattern separation and microglial activation in response to ibuprofen. Transl. Psychiatry 4, e463.

Lovatel, G.A., Elsner, V.R., Bertoldi, K., Vanzella, C., Moyses Fdos, S., Vizuete, A. Spindler, C., Cechinel, L.R., Netto, C.A., Muotri, A.R., Siqueira, I.R., 2013. Treadmill exercise induces age-related changes in aversive memory, neuroinflammatory and epigenetic processes in the rat hippocampus. Neurobiol. Learn. Mem. 101, 94-102.

Lucassen, P.J., Oomen, C.A., Naninck, E.F., Fitzsimons, C.P., van Dam, A.M., Czeh, B. Korosi, A., 2015. Regulation of adult neurogenesis and plasticity by (Early) stress, glucocorticoids, and inflammation. Cold Spring Harbor Perspect. Biol. 7 a021303.

Mandrekar-Colucci, S., Landreth, G.E., 2010. Microglia and inflammation in Alzheimer's disease. CNS Neurol. Disord. Drug Targets 9, 156-167.

Marlatt, M.W., Potter, M.C., Lucassen, P.J., van Praag, H., 2012. Running throughout middle-age improves memory function, hippocampal neurogenesis, and BDNF levels in female C57BL/6J mice. Dev. Neurobiol. 72, 943-952.

Marlatt, M.W., Potter, M.C., Bayer, T.A., van Praag, H., Lucassen, P.J., 2013. Prolonged running, not fluoxetine treatment, increases neurogenesis, but does not alter neuropathology, in the 3xTg mouse model of Alzheimer's disease. Curr. Top. Behav. Nneurosci. 15, 313-340.

Matsuda, T., Murao, N., Katano, Y., Juliandi, B., Kohyama, J., Akira, S., Kawai, T. Nakashima, K., 2015. TLR9 signalling in microglia attenuates seizure-induced aberrant neurogenesis in the adult hippocampus. Nat. Commun. 6, 6514
Matt, S.M., Johnson, R.W., 2016. Neuro-immune dysfunction during brain aging: new insights in microglial cell regulation. Curr. Opin. Pharmacol. 26, 96-101.

McGeer, P.L., McGeer, E.G., 2013. The amyloid cascade-inflammatory hypothesis of Alzheimer disease: implications for therapy. Acta Neuropathol. (Berl.) 126, 479-497.

Miller, B.R., Hen, R., 2015. The current state of the neurogenic theory of depression and anxiety. Curr. Opin. Neurobiol. 30, 51-58.

Minogue, A.M., Jones, R.S., Kelly, R.J., McDonald, C.L., Connor, T.J., Lynch, M.A., 2014 Age-associated dysregulation of microglial activation is coupled with enhanced blood-brain barrier permeability and pathology in APP/PS1 mice. Neurobiol. Aging 35, 1442-1452.

Mirochnic, S., Wolf, S., Staufenbiel, M., Kempermann, G., 2009. Age effects on the regulation of adult hippocampal neurogenesis by physical activity and environmental enrichment in the APP23 mouse model of Alzheimer disease. Hippocampus 19, 1008-1018.

Mohan, A., Mather, K.A., Thalamuthu, A., Baune, B.T., Sachdev, P.S., 2016. Gene expression in the aging human brain: an overview. Curr. Opin. Psychiatry 29 $159-167$.

Monje, M.L., Toda, H., Palmer, T.D., 2003. Inflammatory blockade restores adult hippocampal neurogenesis. Science (New York, N. Y.) 302, 1760-1765.

Moon, M., Cha, M.Y., Mook-Jung, I., 2014. Impaired hippocampal neurogenesis and its enhancement with ghrelin in 5XFAD mice. J. Alzheimers Dis. 41, 233-241.

Moore, K.M., Girens, R.E., Larson, S.K., Jones, M.R., Restivo, J.L., Holtzman, D.M., Cirrito, J.R., Yuede, C.M., Zimmerman, S.D., Timson, B.F., 2015. A spectrum of exercise training reduces soluble Abeta in a dose-dependent manner in a mouse model of Alzheimer's disease. Neurobiol. Dis. 85, 218-224.

Mucke, L., Masliah, E., Yu, G.Q., Mallory, M., Rockenstein, E.M., Tatsuno, G., Hu, K., Kholodenko, D., Johnson-Wood, K., McConlogue, L., 2000. High-level neurona expression of abeta 1-42 in wild-type human amyloid protein precursor transgenic mice: synaptotoxicity without plaque formation. J. Neurosci. 20, 4050-4058

Mustroph, M.L., Chen, S., Desai, S.C., Cay, E.B., DeYoung, E.K., Rhodes, J.S., 2012. Aerobic exercise is the critical variable in an enriched environment that increases hippocampal neurogenesis and water maze learning in male C57BL/6J mice. Neuroscience 219, 62-71.

Nagele, R.G., D’Andrea, M.R., Lee, H., Venkataraman, V., Wang, H.Y., 2003. Astrocytes accumulate A beta 42 and give rise to astrocytic amyloid plaques in Alzheimer disease brains. Brain Res. 971, 197-209.

Naylor, A.S., Persson, A.I., Eriksson, P.S., Jonsdottir, I.H., Thorlin, T., 2005. Extended voluntary running inhibits exercise-induced adult hippocampal progenitor proliferation in the spontaneously hypertensive rat. J. Neurophysiol. 93 , 2406-2414

Nichol, K.E., Parachikova, A.I., Cotman, C.W., 2007. Three weeks of running wheel exposure improves cognitive performance in the aged Tg2576 mouse. Behav. Brain Res. 184, 124-132.

Niibori, Y., Yu, T.S., Epp, J.R., Akers, K.G., Josselyn, S.A., Frankland, P.W., 2012. Suppression of adult neurogenesis impairs population coding of similar contexts in hippocampal CA3 region. Nat. Commun. 3, 1253.

Nikas, J.B., 2013. Inflammation and immune system activation in aging: mathematical approach. Sci. Rep. 3, 3254.

Oakley, H., Cole, S.L., Logan, S., Maus, E., Shao, P., Craft, J., Guillozet-Bongaarts, A., Ohno, M., Disterhoft, J., Van Eldik, L., Berry, R., Vassar, R., 2006. Intraneuronal beta-amyloid aggregates, neurodegeneration, and neuron loss in transgenic mice with five familial Alzheimer's disease mutations: potential factors in amyloid plaque formation. J. Neurosci. 26, 10129-10140.

Oddo, S., Caccamo, A., Shepherd, J.D., Murphy, M.P., Golde, T.E., Kayed, R., Metherate, R., Mattson, M.P., Akbari, Y., LaFerla, F.M., 2003. Triple-transgenic model of Alzheimer's disease with plaques and tangles: intracellular Abeta and synaptic dysfunction. Neuron 39, 409-421.

Oomen, C.A., Bekinschtein, P., Kent, B.A., Saksida, L.M., Bussey, T.J., 2014. Adult hippocampal neurogenesis and its role in cognition. Wiley Interdiscip. Rev. Cogn. Sci. 5, 573-587.

Palmer, T.D., Willhoite, A.R., Gage, F.H., 2000. Vascular niche for adult hippocampal neurogenesis. J. Comp. Neurol. 425, 479-494.

Parachikova, A., Nichol, K.E., Cotman, C.W., 2008. Short-term exercise in aged Tg2576 mice alters neuroinflammation and improves cognition. Neurobiol. Dis, 30, 121-129.

Paton, J.A., Nottebohm, F.N., 1984. Neurons generated in the adult brain are recruited into functional circuits. Science 225, 1046-1048.

Patten, A.R., Sickmann, H., Hryciw, B.N., Kucharsky, T., Parton, R., Kernick, A., Christie, B.R., 2013. Long-term exercise is needed to enhance synaptic plasticity in the hippocampus. Learn. Mem. 20, 642-647.

Pereira, A.C., Huddleston, D.E., Brickman, A.M., Sosunov, A.A., Hen, R., McKhann, G.M., Sloan, R., Gage, F.H., Brown, T.R., Small, S.A., 2007. An in vivo correlate of exercise-induced neurogenesis in the adult dentate gyrus. Proc. Natl. Acad. Sci. U. S. A. $104,5638-5643$

Perry, E.K., Johnson, M., Ekonomou, A., Perry, R.H., Ballard, C., Attems, J., 2012. Neurogenic abnormalities in Alzheimer's disease differ between stages of neurogenesis and are partly related to cholinergic pathology. Neurobiol. Dis. 47, 155-162.

Pristera, A., Saraulli, D., Farioli-Vecchioli, S., Strimpakos, G., Costanzi, M., di Certo, M.G., Cannas, S., Ciotti, M.T., Tirone, F., Mattei, E., Cestari, V., Canu, N., 2013. Impact of $\mathrm{N}$-tau on adult hippocampal neurogenesis, anxiety, and memory. Neurobiol. Aging 34, 2551-2563.

Quintana-Hernandez, D.J., Miro-Barrachina, M.T., Ibanez-Fernandez, I.J., Pino, A.S. Quintana-Montesdeoca, M.P., Rodriguez-de Vera, B., Morales-Casanova, D., 
Perez-Vieitez Mdel, C., Rodriguez-Garcia, J., Bravo-Caraduje, N., 2015. Mindfulness in the maintenance of cognitive capacities in Alzheimer's disease: a randomized clinical trial. J. Alzheimers Dis. 50, 217-232.

Rao, M.S., Hattiangady, B., Shetty, A.K., 2006. The window and mechanisms of major age-related decline in the production of new neurons within the dentate gyrus of the hippocampus. Aging Cell 5, 545-558.

Ravaglia, G., Forti, P., Lucicesare, A., Pisacane, N., Rietti, E., Bianchin, M., Dalmonte, E., 2008. Physical activity and dementia risk in the elderly: findings from a prospective Italian study. Neurology 70, 1786-1794.

Redila, V.A., Christie, B.R., 2006. Exercise-induced changes in dendritic structure and complexity in the adult hippocampal dentate gyrus. Neuroscience 137, 1299-1307.

Reiter, K., Nielson, K.A., Smith, T.J., Weiss, L.R., Alfini, A.J., Smith, J.C., 2015. Improved cardiorespiratory fitness is associated with increased cortical thickness in mild cognitive impairment. J. Int. Neuropsychol. Soc.: JINS 21, 757-767.

Revilla, S., Sunol, C., Garcia-Mesa, Y., Gimenez-Llort, L., Sanfeliu, C., Cristofol, R., 2014. Physical exercise improves synaptic dysfunction and recovers the loss of survival factors in 3xTg-AD mouse brain. Neuropharmacology 81, 55-63.

Rockenstein, E., Mallory, M., Mante, M., Sisk, A., Masliaha, E., 2001. Early formation of mature amyloid-beta protein deposits in a mutant APP transgenic model depends on levels of Abeta (1-42). J. Neurosci. Res. 66, 573-582.

Rodriguez, J.J., Jones, V.C., Tabuchi, M., Allan, S.M., Knight, E.M., LaFerla, F.M., Oddo, S., Verkhratsky, A., 2008. Impaired adult neurogenesis in the dentate gyrus of a triple transgenic mouse model of Alzheimer's disease. PLoS One 3, e2935.

Rodriguez, J.J., Witton, J., Olabarria, M., Noristani, H.N., Verkhratsky, A., 2010. Increase in the density of resting microglia precedes neuritic plaque formation and microglial activation in a transgenic model of Alzheimer's disease. Cell Death Dis. 1, e1

Rodriguez, J.J., Noristani, H.N., Olabarria, M., Fletcher, J., Somerville, T.D., Yeh, C.Y., Verkhratsky, A., 2011. Voluntary running and environmental enrichment restores impaired hippocampal neurogenesis in a triple transgenic mouse model of Alzheimer's disease. Curr. Alzheimer Res. 8, 707-717.

Sastre, M., Klockgether, T., Heneka, M.T., 2006. Contribution of inflammatory processes to Alzheimer's disease: molecular mechanisms. Int. J. Dev. Neurosci. $24,167-176$

Saxe, M.D., Battaglia, F., Wang, J.-W.W., Malleret, G., David, D.J., Monckton, J.E., Garcia, A.D., Sofroniew, M.V., Kandel, E.R., Santarelli, L., Hen, R., Drew, M.R. 2006. Ablation of hippocampal neurogenesis impairs contextual fear conditioning and synaptic plasticity in the dentate gyrus. Proc. Natl. Acad. Sci. U.S.A. 103, 17501-17506.

Schindowski, K., Bretteville, A., Leroy, K., Begard, S., Brion, J.P., Hamdane, M., Buee, L., 2006. Alzheimer's disease-like tau neuropathology leads to memory deficits and loss of functional synapses in a novel mutated tau transgenic mouse without any motor deficits. Am. J. Pathol. 169, 599-616.

Sennvik, K., Boekhoorn, K., Lasrado, R., Terwel, D., Verhaeghe, S., Korr, H., Schmitz, C., Tomiyama, T., Mori, H., Krugers, H., Joels, M., Ramakers, G.J., Lucassen, P.J., Van Leuven, F., 2007. Tau-4R suppresses proliferation and promotes neuronal differentiation in the hippocampus of tau knockin/knockout mice. FASEB J. 21 2149-2161.

Shadfar, S., Hwang, C.J., Lim, M.S., Choi, D.Y., Hong, J.T., 2015. Involvement of inflammation in Alzheimer's disease pathogenesis and therapeutic potential of anti-inflammatory agents. Arch. Pharmacal Res. 38, 2106-2119.

Shors, T.J., Miesegaes, G., Beylin, A., Zhao, M., Rydel, T., Gould, E., 2001. Neurogenesis in the adult is involved in the formation of trace memories. Nature 410, 372-376.

Shruster, A., Offen, D., 2014. Targeting neurogenesis ameliorates danger assessment in a mouse model of Alzheimer's disease. Behav. Brain Res. 261 193-201.

Snyder, J.S., Hong, N.S., McDonald, R.J., Wojtowicz, J.M., 2005. A role for adult neurogenesis in spatial long-term memory. Neuroscience 130, 843-852.

Spalding, K.L., Bergmann, O., Alkass, K., Bernard, S., Salehpour, M., Huttner, H.B. Boström, E., Westerlund, I., Vial, C., Buchholz, B.A., Possnert, G., Mash, D.C., Druid, H., Frisén, J., 2013. Dynamics of hippocampal neurogenesis in adult humans. Cell 153, 1219-1227.

Sturchler-Pierrat, C., Abramowski, D., Duke, M., Wiederhold, K.H., Mistl, C., Rothacher, S., Ledermann, B., Burki, K., Frey, P., Paganetti, P.A., Waridel, C., Calhoun, M.E., Jucker, M., Probst, A., Staufenbiel, M., Sommer, B., 1997. Two amyloid precursor protein transgenic mouse models with Alzheimer disease-like pathology. Proc. Natl. Acad. Sci. U. S. A. 94, 13287-13292.

Taniuchi, N., Niidome, T., Goto, Y., Akaike, A., Kihara, T., Sugimoto, H., 2007. Decreased proliferation of hippocampal progenitor cells in APPswe/PS1dE9 transgenic mice. Neuroreport 18, 1801-1805.

Tapia-Rojas, C., Aranguiz, F., Varela-Nallar, L., Inestrosa, N.C., 2016. Voluntary running attenuates memory loss, decreases neuropathological changes and induces neurogenesis in a mouse model of Alzheimer's disease. Brain Pathol. (Zurich, Switzerland) 26, 62-74.

Tarkowski, E., Andreasen, N., Tarkowski, A., Blennow, K., 2003. Intrathecal inflammation precedes development of Alzheimer's disease. J. Neurol. Neurosurg. Psychiatry 74, 1200-1205.

Tchantchou, F., Xu, Y., Wu, Y., Christen, Y., Luo, Y., 2007. EGb 761 enhances adult hippocampal neurogenesis and phosphorylation of CREB in transgenic mouse model of Alzheimer's disease. FASEB J. 21, 2400-2408.
Um, H.S., Kang, E.B., Koo, J.H., Kim, H.T., Jin, L., Kim, E.J., Yang, C.H., An, G.Y., Cho, I.H., Cho, J.Y., 2011. Treadmill exercise represses neuronal cell death in an aged transgenic mouse model of Alzheimer's disease. Neurosci. Res. 69, 161-173.

Valero, J., Espana, J., Parra-Damas, A., Martin, E., Rodriguez-Alvarez, J., Saura, C.A. 2011. Short-term environmental enrichment rescues adult neurogenesis and memory deficits in APP(Sw,Ind) transgenic mice. PLoS One 6, e16832.

Van de Winckel, A., Feys, H., De Weerdt, W., Dom, R., 2004. Cognitive and behavioural effects of music-based exercises in patients with dementia. Clin. Rehabil. 18, 253-260.

Van der Borght, K., Kobor-Nyakas, D.E., Klauke, K., Eggen, B.J., Nyakas, C., Van der Zee, E.A., Meerlo, P., 2009. Physical exercise leads to rapid adaptations in hippocampal vasculature: temporal dynamics and relationship to cell proliferation and neurogenesis. Hippocampus 19, 928-936.

Venturelli, M., Scarsini, R., Schena, F., 2011. Six-month walking program changes cognitive and ADL performance in patients with Alzheimer. Am. J. Alzheimer's Dis. Other Demen. 26, 381-388.

Verdaguer, E., Brox, S., Petrov, D., Olloquequi, J., Romero, R., de Lemos, M.L., Camins, A., Auladell, C., 2015. Vulnerability of calbindin, calretinin and parvalbumin in a transgenic/knock-in APPswe/PS1dE9 mouse model of Alzheimer disease together with disruption of hippocampal neurogenesis. Exp. Gerontol. 69, 176-188.

Verwer, R.W., Sluiter, A.A., Balesar, R.A., Baayen, J.C., Noske, D.P., Dirven, C.M., Wouda, J., van Dam, A.M., Lucassen, P.J., Swaab, D.F., 2007. Mature astrocytes in the adult human neocortex express the early neuronal marker doublecortin. Brain: A J. Neurol. 130, 3321-3335.

Villasana, L.E., Westbrook, G.L., Schnell, E., 2014. Neurologic impairment following closed head injury predicts post-traumatic neurogenesis. Exp. Neurol. 261, 156-162.

Vreugdenhil, A., Cannell, J., Davies, A., Razay, G., 2012. A community-based exercise programme to improve functional ability in people with Alzheimer's disease: a randomized controlled trial. Scand. J. Caring Sci. 26, 12-19.

Walker, J.M., Klakotskaia, D., Ajit, D., Weisman, G.A., Wood, W.G., Sun, G.Y., Serfozo P., Simonyi, A., Schachtman, T.R., 2015. Beneficial effects of dietary EGCG and voluntary exercise on behavior in an Alzheimer's disease mouse model. J. Alzheimers Dis. 44, 561-572.

Winocur, G., Wojtowicz, J.M., Sekeres, M., Snyder, J.S., Wang, S., 2006. Inhibition of neurogenesis interferes with hippocampus-dependent memory function. Hippocampus 16, 296-304.

Wrann, C.D., White, J.P., Salogiannis, J., Laznik-Bogoslavski, D., Wu, J., Ma, D., Lin, J.D., Greenberg, M.E., Spiegelman, B.M., 2013. Exercise induces hippocampal BDNF through a PGC-1 $\alpha$ /FNDC5 pathway. Cell Metab. 18, 649-659.

Wu, C.W., Chang, Y.T., Yu, L., Chen, H.I., Jen, C.J., Wu, S.Y., Lo, C.P., Kuo, Y.M., 1985 2008: Exercise enhances the proliferation of neural stem cells and neurite growth and survival of neuronal progenitor cells in dentate gyrus of middle-aged mice. J. Appl. Physiol. 105, 1585-1594.

Xu, Z.Q., Zhang, L.Q., Wang, Q., Marshall, C., Xiao, N., Gao, J.Y., Wu, T., Ding, J., Hu, G., Xiao, M., 2013. Aerobic exercise combined with antioxidative treatment does not counteract moderate- or mid-stage Alzheimer-like pathophysiology of APP/PS1 mice. CNS Neurosci. Ther. 19, 795-803.

Yau, S.Y., Gil-Mohapel, J., Christie, B.R., So, K.F., 2014. Physical exercise-induced adult neurogenesis: a good strategy to prevent cognitive decline in neurodegenerative diseases? BioMed. Res. Int. 2014, 403120.

Yu, Y., He, J., Zhang, Y., Luo, H., Zhu, S., Yang, Y., Zhao, T., Wu, J., Huang, Y., Kong, J., Tan, Q., Li, X.M., 2009. Increased hippocampal neurogenesis in the progressive stage of Alzheimer's disease phenotype in an APP/PS1 double transgenic mouse model. Hippocampus 19, 1247-1253.

Yudkin, J.S., 2007. Inflammation, obesity, and the metabolic syndrome. Horm. Metab. Res. 39, 707-709.

Yuede, C.M., Zimmerman, S.D., Dong, H., Kling, M.J., Bero, A.W., Holtzman, D.M., Timson, B.F., Csernansky, J.G., 2009. Effects of voluntary and forced exercise on plaque deposition, hippocampal volume, and behavior in the Tg2576 mouse model of Alzheimer's disease. Neurobiol. Dis. 35, 426-432.

Zaheer, S., Thangavel, R., Wu, Y., Khan, M.M., Kempuraj, D., Zaheer, A., 2013. Enhanced expression of glia maturation factor correlates with glial activation in the brain of triple transgenic Alzheimer's disease mice. Neurochem. Res. 38, 218-225.

de Andrade, L.P., Gobbi, L.T., Coelho, F.G., Christofoletti, G., Costa, J.L., Stella, F., 2013. Benefits of multimodal exercise intervention for postural control and frontal cognitive functions in individuals with Alzheimer's disease: a controlled trial. J. Am. Geriatr. Soc. 61, 1919-1926.

van Praag, H., Christie, B.R., Sejnowski, T.J., Gage, F.H., 1999a. Running enhances neurogenesis, learning, and long-term potentiation in mice. Proc. Natl. Acad. Sci. U.S.A. 96, 13427-13431.

van Praag, H., Kempermann, G., Gage, F.H., 1999b. Running increases cell proliferation and neurogenesis in the adult mouse dentate gyrus. Nat. Neurosci. 2, 266-270.

von Bernhardi, R., Eugenin-von Bernhardi, L., Eugenin, J., 2015. Microglial cell dysregulation in brain aging and neurodegeneration. Front. Aging Neurosci. 7 , 124.

Zhao, G., Liu, H.L., Zhang, H., Tong, X.J., 2015. Treadmill exercise enhances synaptic plasticity, but does not alter beta-amyloid deposition in hippocampi of aged APP/PS1 transgenic mice. Neuroscience 298, 357-366. 